\title{
Chitin of Araneae origin: structural features and biomimetic applications: a review
}

\author{
Tomasz Machałowski $^{1,2}$ [C $\cdot$ Chris Amemiya $^{3} \cdot$ Teofil Jesionowski $^{1}$
}

Received: 2 May 2020 / Accepted: 30 July 2020

(C) The Author(s) 2020

\begin{abstract}
Large scale isolation of chitin traditionally has been carried out from fungal biomass as well as from seafood processing wastes, e.g., from shrimp, crab and lobster exoskeletons. Despite the relative abundance and ready availability of these materials, isolation of chitin requires great deal of chemical reagents and is time consuming. Obtained in this way chitin is produced in the form of powders, whiskers, and flakes. In this review, we have focused on the moulting cuticles of spiders as an alternative source of naturally occurring chitin. The comparatively high chitin content in the moults allows for rapid preparation of structures that maintain their original shape and integrity, such as the chitinous tubes from leg exoskeletons. Based on our latest scientific analyses regarding spider chitin, we highlight here its advantages and its biomimetic applications in tissue engineering, catalysis and environmental science.
\end{abstract}

Keywords Spider chitin $\cdot$ Tubular chitin $\cdot$ Biopolymers $\cdot$ Biomimetics $\cdot$ Scaffold

\section{Introduction}

In recent years, there has been a significant increase in the study of natural polysaccharides [1-9]. This interest is largely spurred on by their attractive and usable properties, such as ecofriendly characteristics, renewability, biodegradability and cost-efficiency $[8,10]$. It is well known that chitin is one of the most abundant (after cellulose) natural biopolymer worldwide $[11,12]$. According to a recent report, living organisms from oceans produce approximately $10^{12}-10^{14}$ tons of chitin annually [13]. Chitin exists as a rigid crystalline nanofiber with Young's modulus of 40-80 GPa [10]. In its pure form, chitin exists as a linear homopolymer of $N$-acetylglucosamine (GlcNAc) linked by $\beta-1,4$

Tomasz Machałowski

tomasz.g.machalowski@ doctorate.put.poznan.pl

Teofil Jesionowski

teofil.jesionowski@put.poznan.pl

1 Institute of Chemical Technology and Engineering, Faculty of Chemical Technology, Poznan University of Technology, 60965 Poznan, Poland

2 Institute of Electronics and Sensor Materials, TU Bergakademie Freiberg, 09599 Freiberg, Germany

3 Department of Molecular and Cell Biology, University of California-Merced, Merced, CA 95343, USA glycosidic bonds with various degrees of deacetylated glucosamine $(\mathrm{GlcN})$ residues (dependent on origin and isolation method) [12]. This polysaccharide is synthesized by a broad assortment of organisms representing different taxonomic groups. Notable examples are fungi (e.g., from the mycelia of Aspergillus niger, Mucor rouxii, Agaricus bisporus) [12, 14-16], diatoms [17-19], protists [20, 21], sponges [22-25], molluscs [26-29], insects [10, 30-35], spiders [36] and crustaceans [37-41]. Moreover, chitin has also been recognized in multiple structures in fishes and amphibians [42-44]. In invertebrates, chitin usually acts as a fibrillar component of mechanically resilient biocomposites, like eggshells, cuticles, cuttlebones, shell and sponge scaffolds [45-48].

Chitin distributed in nature possesses three different crystalline allomorphic forms which differ in their arrangement of chitin strands to one-another: $\alpha$-chitin, $\beta$-chitin and $\gamma$-chitin [49]. The ubiquitous $\alpha$-form (found, e.g., in arthropods skeletons) is also the most thermodynamically stable form of the three. Correspondingly, additional inter-sheet hydrogen bonds present in $\alpha$-chitin allow a tighter anti-parallel fiber arrangement. Consequently, this is reflected in difficulties in aqueous dissolution and solvent selection [50]. Nevertheless, due to its widespread abundance, chitin draws special scientific attention, which may broadly be divided into two areas. The first concerns isolation and description of chitin from diverse phyla [33, 45, 51-53]. The second 
focuses on practical technological applications, including its use in biomedicine, regenerative medicine, filtration devices [54-59], and draws inspiration from the structure of naturally occurring chitin and its derivatives (i.e., chitosan) [14, 60-67].

Here, we posit that a highly promising and unique source of chitin can be readily obtained from spiders (Araneae), which "shed" large quantities of chitin-containing cuticles (exoskeletons) during their life cycle (see Fig. 1). To grow, spiders (like other arthropods) must form a new, larger exoskeleton and shed the old one, this moulting process (ecdysis) occurring several times per year $[60,68]$. The main purpose of "changing skin" is to enable growth (10-16\%) [68] and allow further development of the body (i.e., ensures attaining sexual maturation) [61]. It has been estimated, that the fresh weight of the global spider community amounts to 25 million metric tons [62]. These calculations were obtained by determination of average spiders' biomass per square meter in various terrestrial biotopes around the world. In another report, it has been estimated that all spider species lose about $8 \pm 0.16 \%$ of mass during a moult [60]. By these measures, we can estimate that spiders are able to produce between 2 and 6 million tons of cuticles due to ecdysis worldwide per year (depending on the frequency of moulting). Surprisingly, despite their diversity and widespread distribution, Araneae have received only scant attention with respect to utilization of their moults as a potential, renewable source of chitin. It is also worth noting that spiders, especially from Theraphosidae family (so-called "birdeating spiders" or "tarantulas") are very popular showpieces among the spider hobbyist community [63]. The number of such spiders in Europe may number approximately 2 million [64]. Spider cuticles lost after ecdysis, though overlooked for years, can thus provide a rich source of chitin. Recently, chitin isolated from spider moults has found diverse uses, including scaffolds for tissue engineering, porous membranes for catalyst creation [65], and as crude oil sorbents [66].

\section{Spider taxonomy and morphology}

Taxonomically, spiders (Araneae) comprise a large group of invertebrates containing more than 4000 genera $[67,69,70]$. According to an online taxonomic catalogue of the world's spider fauna, 48,400 species of spiders have been described worldwide [71]. Their representatives occupy almost all habitats with the exception of Antarctica. They have existed at least since the carboniferous times ( 320 million years), twice as long as the oldest mammals [72]. An especially interesting group within the Araneae is the Theraphosidae, whose exoskeleton moults are a potentially valuable chitin source. Theraphosid specimens can reach lengths of over $25 \mathrm{~cm}$ and the moults they shed are quite substantial. Theraphosidae is the main family of mygalomorph spiders, with about 900 described species worldwide distributed among 11 subfamilies [73, 74]. The representatives of this family are distributed among the Americas, Africa, southern Europe, the Middle East, Asia, and Australia, primarily in tropical zones [73, 75].

Spiders are very different anatomically compared to other arthropods. The body of a spider can be divided into two main parts (regions): the anterior cephalothorax (prosoma) which represents a fusion of the head and thoracic segments, and the abdomen (opisthosoma), see Fig. 2a, b [67].
Fig. 1 Cuticle moults from diverse Theraphosidae species represent an accessible bulk waste biological source for chitin isolation

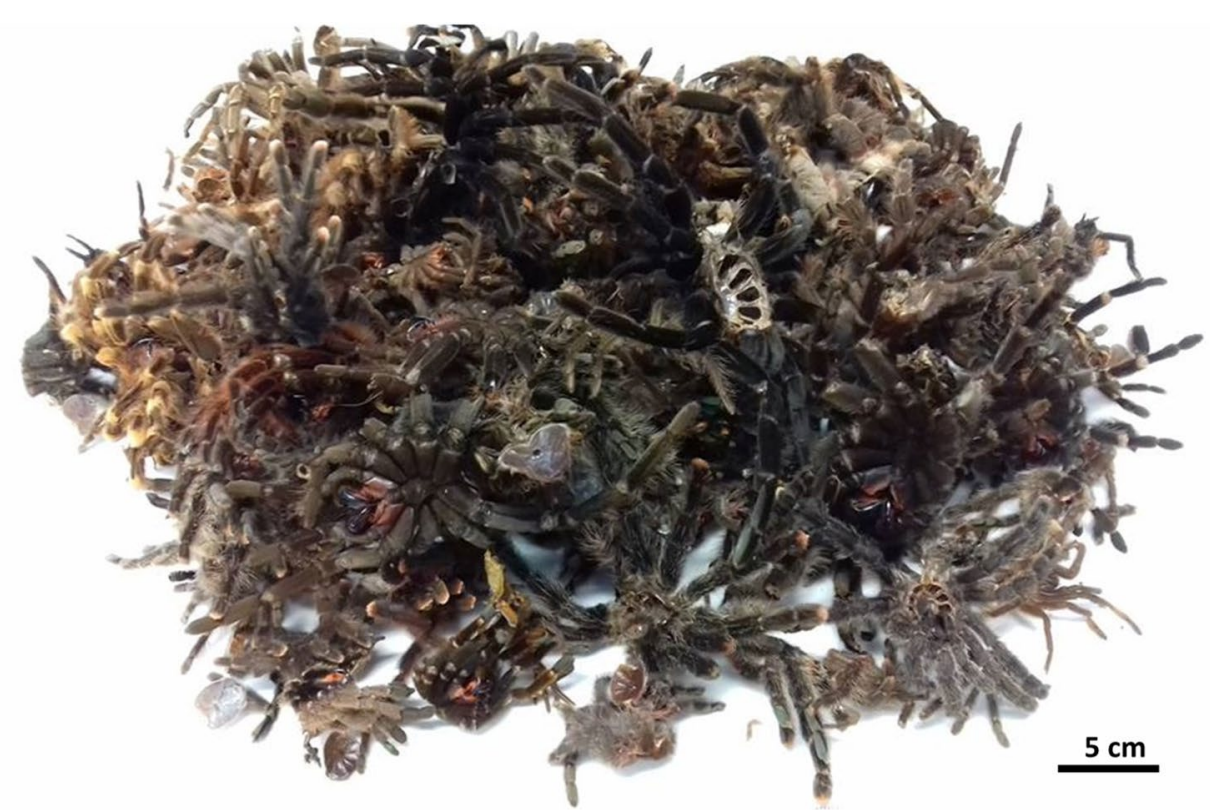



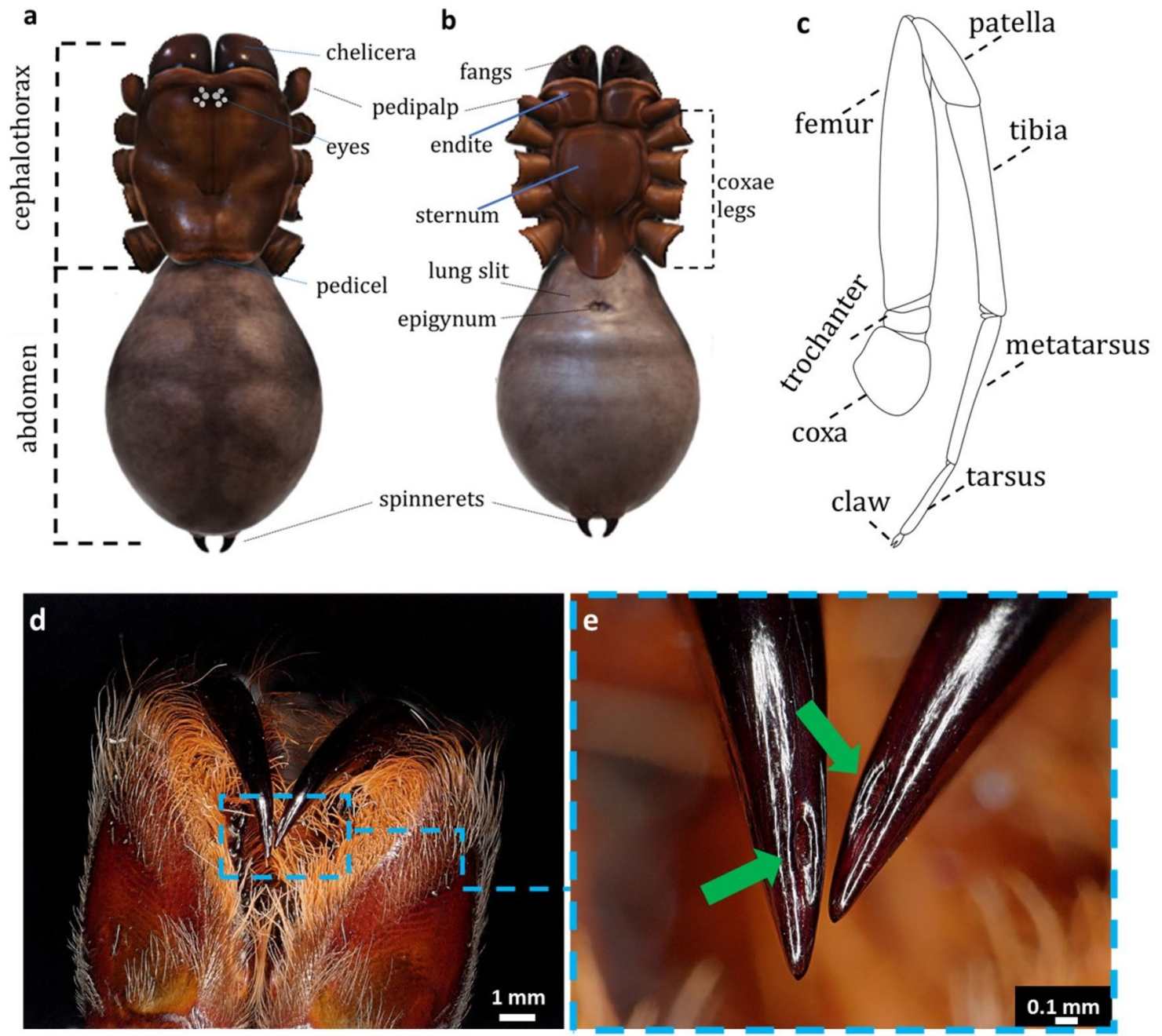

Fig. 2 Model of the morphology of representative spider cephalothorax, abdomen and leg and fangs. Dorsal (a) and ventral (b) view of cephalothorax and abdomen. Morphology of a spider leg shows the seven segments (c). Spiders possess a patella and metatarsus, which

In contrast to insects, spiders have four pairs of walking legs, each with seven segments: coxa, trochanter, femur, patella, tibia, metatarsus, and tarsus (see Fig. 2c).

All spiders have one pair of chelicera (see Fig. 2d) which is located on the front side of the body and are employed to seize, maintain or to bite prey defensively when threatened. They are also used for other purposes, such as digging burrows, moving various elements of the environment (e.g., leaves, soil), protecting and moving the cocoon with eggs, crushing captured bodies of victims and removing food remains from the hideout [76]. Each chelicera consists of two parts: a stout basal portion and a movable fang [67]. The end of the fang is strongly narrowed and sharp, while the part directly connecting to the basal element is much more sizable [76]. Further, we note an interesting fact that some spiders can emit sounds by rubbing together their chelicera. are not found in insects, based on [67]. Digital microscopy photos of Theraphosidae specimens Caribena versciolor chelicera in two maginifications (d). The holes in the fangs (green arrows) are used to release venom (e)

The theraphosids use it as a defense mechanism, i.e., sounds generated in this manner are able to scare away potential enemies. Recently, spider fangs (see Fig. 2e) have been described as consisting of unique biocomposites, composed of chitin, proteins and metal ion cross-linking (Zn-doped crystals) (see [77-80]). As noted by Bar-On and co-workers in article concerning the functionality of the spider fang, "understanding the mechanical functionalities of hierarchically graded natural materials is expected to lead to the development of novel bioinspired engineering materials with superior characteristics" [78].

\subsection{Brief characterization of spider's cuticle}

A more thorough understanding of cuticle composition and corresponding structure-function relationships between 
individual elements is requisite for the use of spider's cuticle for modern bioinspired materials and for biomimetics. It is well recognized, that the body of Araneae is covered with a strong exoskeletal cuticle, encompassing laminated composite material [81-88]. The architecture of the cuticle is dominated by elongated chitinous microfibers coated with protein. Therefore, chitin acts as a chief tensile component and polypeptides serve as the binder material or matrix in which they are embedded [33, 83]. It is worth noting, that chitin complexed with cross-linked protein makes up about $90 \%$ of the total organic content of the exoskeleton [64]. As described Barth in 1973, the gross organization of the spider cuticle microfibrils resembles a Bouligand's model. It was observed that microfibers run parallel to the cuticle surface, wherein all fibers within a layer have the same orientation, the arrangement being strictly correlated with cuticle depth (see [83]).

In spiders three different chitin-protein based layers have been observed: the exo-, endocuticle $[33,79,89,90]$ and intermediate mesocuticle [83]. An additional, thin outermost layer, known as the epicuticle has additionally been described [91]. The local variations of cuticle components mentioned above are also observed and show variations with respect to their anatomical locations. Exocuticle is considered as hardest and the most mechanically resistant component of the spider cuticle [83]. Thus, it is absent in such exoskeleton regions as soft opisthosoma, whereas it is particularly well-developed in such regions as cephalothorax or legs. Hormonally controlled (by ecdysones) moulting process possess following steps: separation of epidermis from the old cuticle (apolysis), secretion of moulting fluid, secretion of new cuticle, the digestion and resorption of the part of the old cuticle, and the shedding of old cuticle (ecdysis) [92]. In contrast to insects, the Arachnid cuticle differs with respect to the presence of a mesocuticle in hard regions of the exoskeleton [84]. In the soft regions of the opisthosoma, the mesocuticle constitutes about $90 \%$ of the structure, the remainder being epi- and endocuticle. Both meso- and endocuticle represent analogous variations [83]. The endocuticle is considered to be a comparatively thicker layer and encompasses chitin fibers tightly coated by proteins [91, 93] (beside metatarsus [83]). It is noteworthy that the endocuticle contributes to hard cuticles as well [83].

Spiders display a large coloration range due to structural variability of their cuticle to differentially reflect light [94], as well as their possession of diverse pigments (i.e., ommochromes, bilins and guanine) [95]. For example, melanincontaining compounds and their derivatives were detected in 14 species of spiders across six families [64, 96].

Besides its role in defense as the major barrier for exoparasites, the cuticle of spiders also serves as muscle attachment points to enable locomotion as well as in particular, play an important role in the reduction of water loss and protecting the spider's body from dehydration (lipid layer) [32]. Previously, it had been shown that cuticle possesses a unique, intricate system of the pore canals [85, 97]. The pore canals and their pores on the cuticle surface have specific diameters of less than $1 \mu \mathrm{m} \mathrm{[36]} \mathrm{and} \mathrm{serve} \mathrm{multiple} \mathrm{roles.} \mathrm{For} \mathrm{exam-}$ ple, McConney [98], observed the domeshaped droplets of epicuticular substances secreted through openings of pore canals of Cupiennius salei cuticlar pad. This observation supports the hypothesis that the pore canals are responsible for secreting the substance from the deeper layers of the cuticle. The Cupiennius salei vascular channels detected in the spider fangs were recognized as elements responsible for the transport of zinc to the tip of the fang to cross-link the protein matrix by binding to histidine residues [77]. This effect is particularly important in ensuring the hardness and strength of this natural biocomposite comprising spider's fangs. Recently, with respect to Caribena versicolor spider moult, larger pores (about $20 \mu \mathrm{m}$ ) were detected during SEM observations. These larger holes in the cuticle are presumed to be caused by setae/hair loss from the moults during the specimen manipulation and preparation [66]. The setae and their connection with the main cuticle at their base also consist mainly of exocuticle covered with epicuticle.

Different structural sections of the cuticle represent a wide array of structural elements, reflecting an extraordinarily broad range of physical and mechanical properties. The Araneae cuticles have a non-homogeneous morphology. Some elements are covered by thick hairs, another possesses a porous cuticle layer, and/or a waxy surface [66]. Examination of the moult of the walking leg of theraphosid spider Avicularia sp. "Peru purple" [66], demonstrated that this element combines two morphologically distinct parts: a brush-like structure of thick hairs and a porous part of the cuticle where setae are connected. The structure of a single hair shows a resemblance to a bird's feather: a main core and micro-hairs protruding from the main core. Three main parts of attachment hairs can be distinguished, i.e., hairy shaft, transition zone and tip region [99]. Size of single hairs covering the cuticle range between 0.5 and $1 \mathrm{~mm}$ in length.

\subsection{Chitin isolation and identification from spider's cuticle}

The first mention of chitin as a structural component of spider exoskeletons was reported in 1892 by Krawkow, as cited in [100]. Then, in the middle of the twentieth century several attempts were made to determine the histology and histochemistry of the Arachnida cuticle [81, 91, 97, 101-103]. Further, in the 1970's Barth focused on detailed characterization of chitinous fibers arrangement into spiders cuticle $[83,85]$. Most recently, many efforts have been made on the characterization of the chemical composition of selected spiders fangs, including texture variation in chitin orientation, 
arrangement, gradients in protein composition and biomechanical functionality [77-79, 93]. In 2013, Erko and coworkers determined lattice parameters and lattice distortions of chitin isolated from Cupiennius salei spider fangs. Authors defined as follow parameters of unit cells $(a=4.6 \AA$, $b=20.6 \AA$ and $c=10.2 \AA$ ) and observed that elongation of the $b$-axis in the spider fang is around $9 \%$, relative to pure $\alpha$-chitin [93]. Nevertheless, the detailed characterization of chitin from other parts of spider cuticle was neglected [36]. In 2014 Kaya and co-workers described physicochemical properties of chitin isolated from two common spider species Geolycosa vultuosa and Hogna radiata [36]. Chitin investigated in their experiments was obtained from dead dried spiders and extracted by a chemical treatment that resulted in a powder. Based on FTIR analysis it was determined that these chitin structures were in $\alpha$-form with high degree of acetylation (97\% for G. vultuosa and $99 \%$ for $H$. radiata, respectively). The $\alpha$-chitin single chains are organized in antiparallel orientation, what reflect a large amount of hydrogen bonds. Based on scanning electron microscopy two types of pores on the cuticle surface in both species were observed. The size (diameter) of former ranged between 190 and $240 \mathrm{~nm}$, while that of the latter were between 11 and $32 \mathrm{~nm}$ in G. vultuosa and $195-260 \mathrm{~nm}$ sized pores in $H$. radiata [36].

In 2016, synchrotron X-ray diffraction analysis was carried out to determine the structure of biogenic $\alpha$-chitin crystals from the tarsal tendon of the spider Cupiennius salei [104]. The authors observed substantial shifts up to $\Delta q / q=9 \%$ in the wave vector in $q$-space, analogous to Erko [93]. These observations were recorded in the (020) diffraction peak position between unpurified cuticular tendon and chitin samples after isolation. It has been inferred that this could be a result of strong protein/chitin and water/chitin interactions (for detail see [104]).

In some organisms, chitin acts as a natural template for biomineralization $[105,106]$. In contrast to other invertebrates, (e.g., sponges, molluscs or crustaceans), the cuticles of spiders are free of minerals such as $\mathrm{CaCO}_{3}$ allowing omission of the demineralization step while isolating chitin. Consequently, chitin isolation may begin immediately with the deproteinization and depigmentation steps, resulting in considerable time and reagents savings (see Fig. 3).

A major breakthrough in the study of chitin isolation from Araneae was made in 2019 by Machalowski and co-workers [64]. An innovative method for chitin isolation from Caribena versicolor spider moults (Fig. 4a) was developed using microwave irradiation (MWI) assisted techniques, allowing a total isolation time of only 6 min (see Fig. 4b). For this purpose, the isolation process is divided into three steps. In the first, cuticular lipids are removed by immersion in chloroform:ethanol ( $\mathrm{v} / \mathrm{v} 2: 1$ ) (together with MWI for $1 \mathrm{~min}$ ). The cuticle is then washed with absolute ethanol and the moult treated with $2.5 \mathrm{M} \mathrm{NaOH}$ solution and MWI for $3 \mathrm{~min}$ for protein denaturation. During this step, the temperature of the solution is increased to $95^{\circ} \mathrm{C}$ and there is a color change
Fig. 3 Overview of chitin isolation procedures from diverse metazoan species. Based on [64]

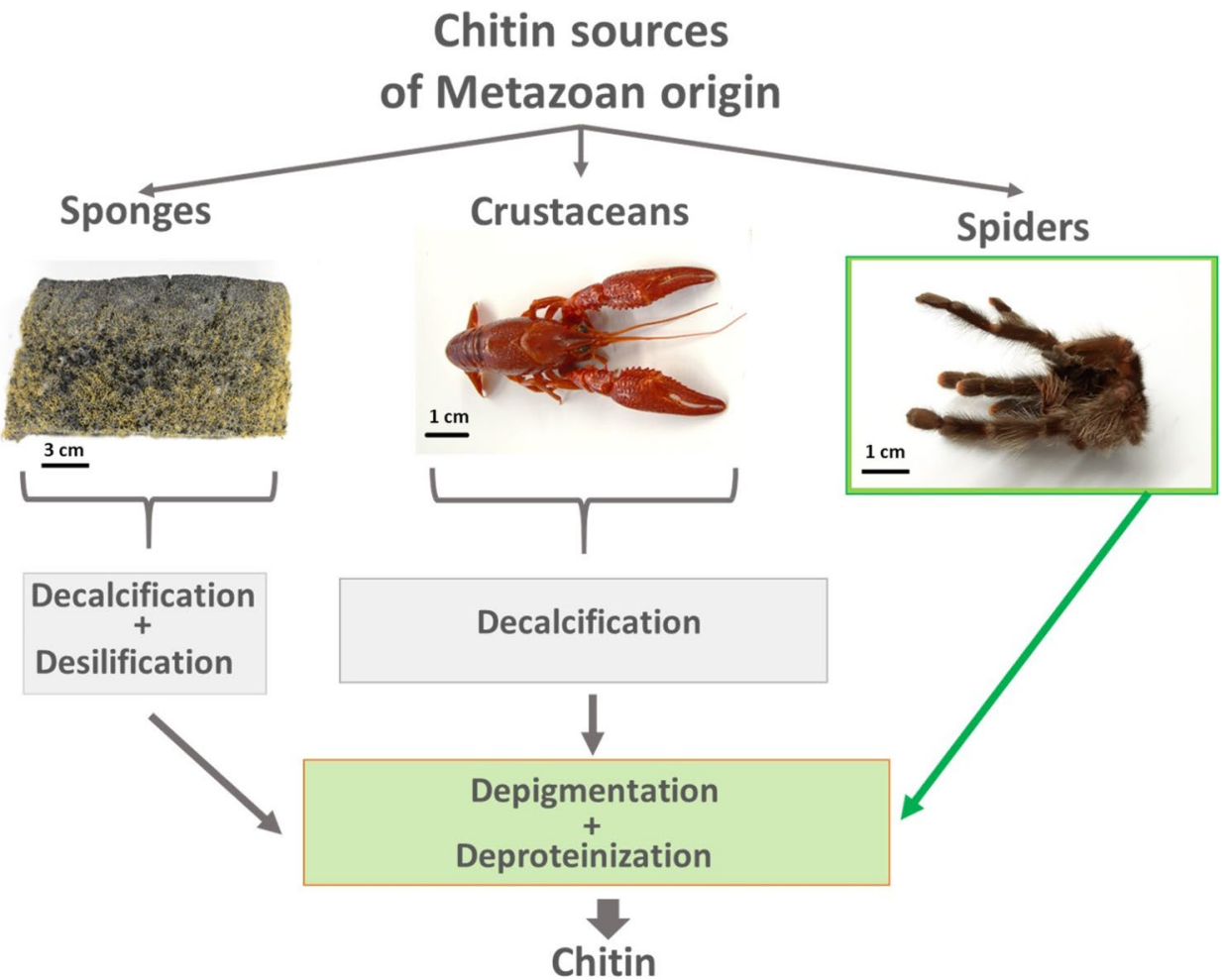


Fig. 4 Moulting cuticle (moult) of the Theraphosidae spider (a). Schematic view of the microwave-assisted method (MWI) for both chitin and pigment isolation (b). Brownish colored pigment and proteolytic extract were obtained after alkali-based treatment (c). The pigment-free, translucent moult represents a source of prefabricated tubular chitin $(\mathbf{d}, \mathbf{e})$ that resembles the shape, size, and morphology of the spider's walking legs. SEM imaginary of chitinous cuticle represent their porous structure in inner (f) and outer side after MWI isolation (g). The two bigger pores (about $50 \mu \mathrm{m}$ ) are locations where formerly mechanosensitive setae were anchored in the cuticle (green arrows) (f). Smaller holes (about $10 \mu \mathrm{m}$ ) are places where non-sensory hairs/setae were anchored in the cuticle before its experimental manipulation (blue arrows) (f)
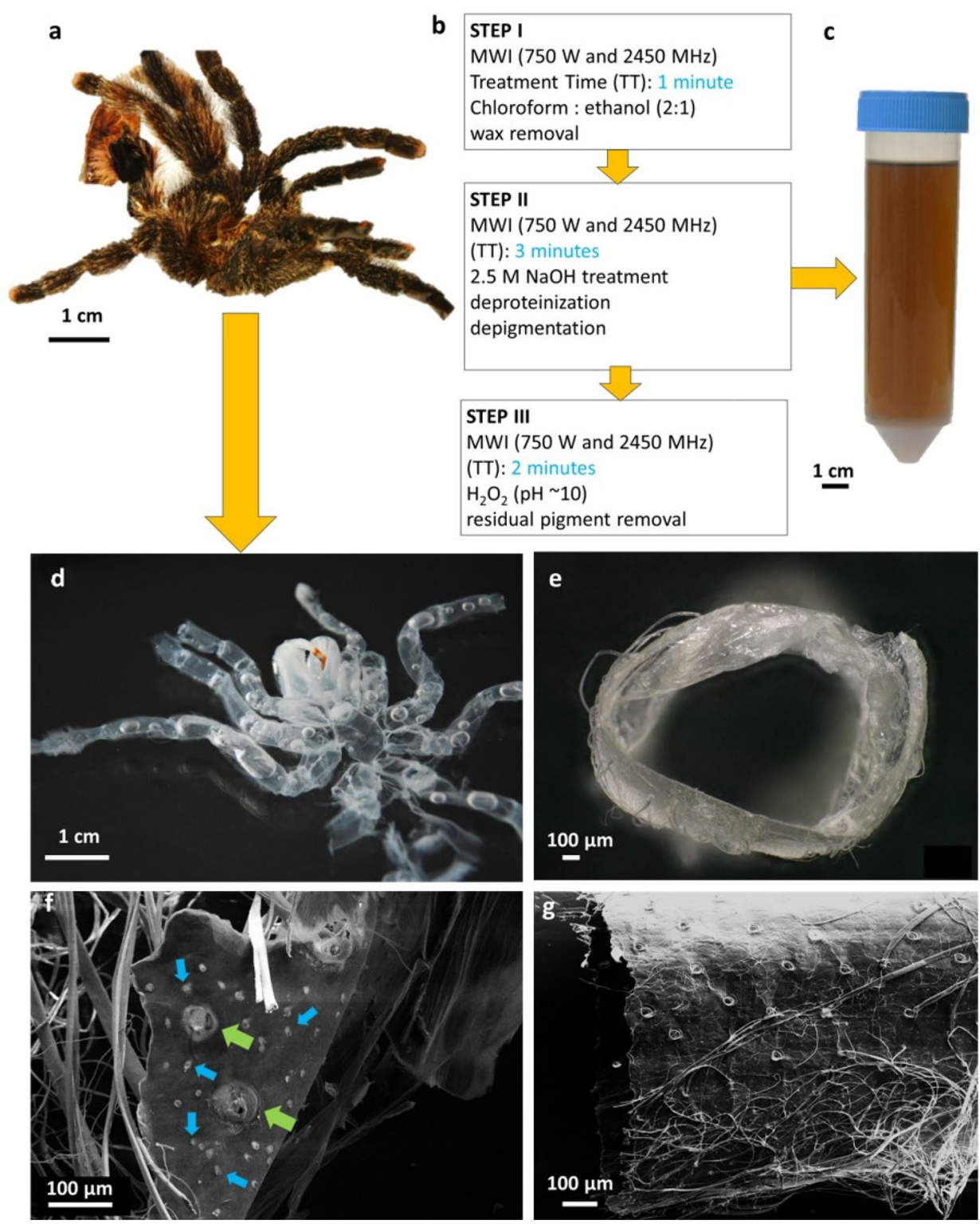

to brown, indicative of proteolysis (Fig. 4b, c). Insoluble material is then carefully separated from the solution and neutralized by several distilled water changes. Finally, the sample is decolorized by utilization of $30 \% \mathrm{H}_{2} \mathrm{O}_{2}(\mathrm{pH} \sim 10$; $\mathrm{pH}$ is regulated by the addition of $2.5 \mathrm{M} \mathrm{NaOH}$ ) under MWI for $2 \mathrm{~min}$. Totally transparent and pliable material obtained by this method (see Fig. $4 \mathrm{~d}-\mathrm{g}$ ) is then washed many times with distilled water and stored at $4{ }^{\circ} \mathrm{C}$. The chitin thus extracted constitutes $19 \%$ of total moult mass and allows analysis of its physical and structural characteristics [64].

In contrast to Kaya et al. [36], Machalowski and others obtained chitin from spider source retaining its unique shapes, including the 3D tubular architecture from walking legs. This result is in agreement with the "scaffolding strategy" concept, whereby higher-order structures are comprised of already prefabricated 3D chitinous scaffolds [107] of both aquatic and terrestrial invertebrates in the form of decellularized matrices. For biotechnological applications, the sources of such constructs should be renewable or represent biodegradable and non-toxic waste materials. Previously, 3D chitinous structures which maintained their natural architecture were isolated from other group of arthropoods. Ideal examples are unique chitinous films obtained from cockroach wings [108, 109], cuticle of honeybee [110], velvet worm [111], cicada [112] or different parts of butterfly cuticle [113]. Looking for an alternative source of chitin is crucial today since chitin extraction from seafood processing waste (e.g., crabs, lobster exoskeletons) is burdened by seasonal and environmental concerns [13], the net result being limitation of local production and high cost of isolation, despite an increased demand [112]. Furthermore, the distinct advantage of isolating chitin from the arthropods 
in 3D form (which has retained its original shape) gives a number of application options because of their structural diversity. For example, the porous type may find application in tissue engineering or adsorption studies. Conversely, smooth and weakly fibrous types of isolated chitin, can be used as covering materials by virtue of their biodegradable, biocompatible, and antimicrobial properties [113].

The biological material isolated from $C$. versicolor moult showed strong calcofluor white (CFW) fluorescence, suggesting the presence of chitin (see Fig. 5a, b). Chitinase digestion resulted in fragmentation and partial dissolution of cuticle fragment after $6 \mathrm{~h}$ of enzymatic digestion (see Fig. $5 c, d)$, indicating that endo-hydrolysis of $N$-acetyl- $\beta$-Dglucosamine- $\beta-(1 \rightarrow 4)$-linkages occurred [64].

A higher resolution analysis method, such as Raman spectroscopy is commonly used to provide detailed insights into the intermolecular interactions of polymers such as polysaccharides and proteins [114]. Raman spectroscopy showed that the spectrum obtained for chitinous spider moult material corresponds to the characteristic spectrum for $\alpha$-chitin (see for details [64]). Moreover, the degree of acetylation (DA\%) and the degree of deacetylation (DD\%) of isolated chitin were determined. The results $(\mathrm{DA}=99 \%$ and $\mathrm{DD}=1 \%$, respectively) indicate that the microwave-assisted technique did not negatively impact chitin acetylation. Isolated material was also analyzed by X-ray diffraction as well as by ${ }^{13} \mathrm{C} \mathrm{CP/MAS} \mathrm{NMR} \mathrm{spectroscopy} \mathrm{(Cross} \mathrm{Polarization/}$ Magic Angle Spinnining Nuclear Magnetic Resonance), results additionally confirming the presence of $\alpha$-chitin. Furthermore, the crystallinity index of isolated chitin was determined to be $99 \%$ (Fig. 6).

\subsubsection{Brief characterization of chitinous setae of spider's cuticle}

Cuticles of insects, spiders or crustaceans are composed mainly of sclerotized chitin and exhibit a wide diversity in appearance. Despite such differences, overt similarities have also been observed for certain morphological structures as a result of evolutionary constraints or convergences. A notable example is the presence of cuticular setae or mechanosensory hairs [106]. These structures, which are involved in
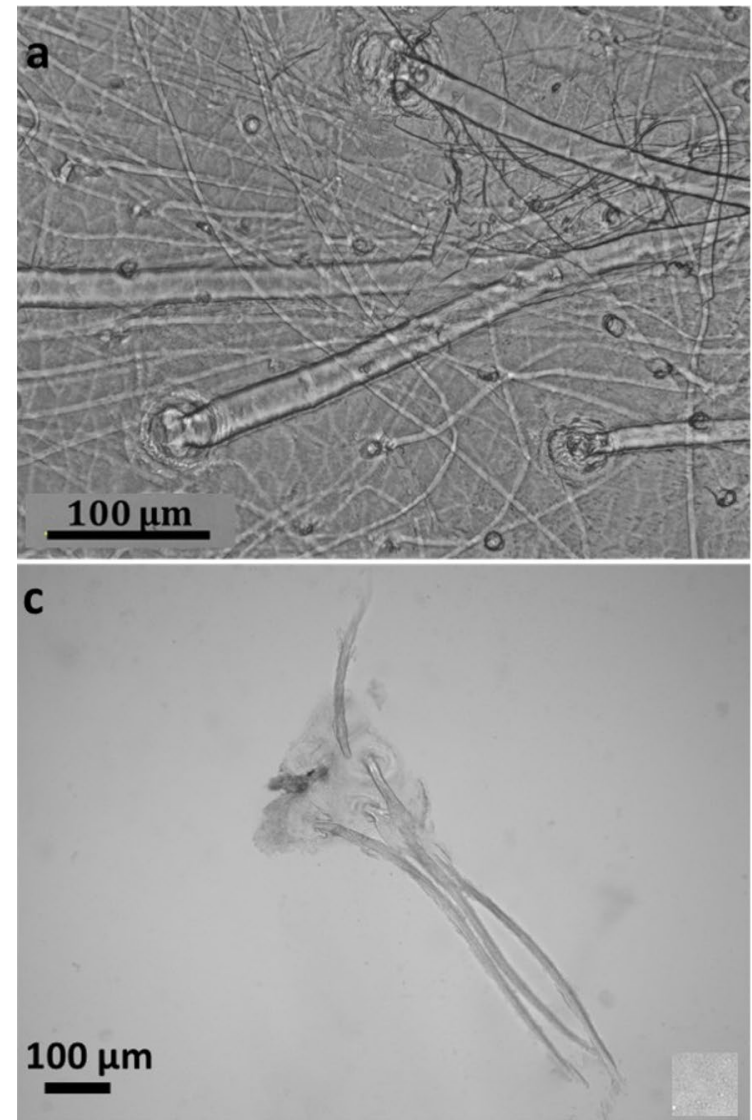

Fig. 5 Confirmation of chitin by calcofluor white staining and chitinase digestion. A selected fragment of chitinous cuticle isolated from $C$. versicolor was stained with calcofluor white and imaged using (a) light microscopy and (b) fluorescence microscopy. A frag-

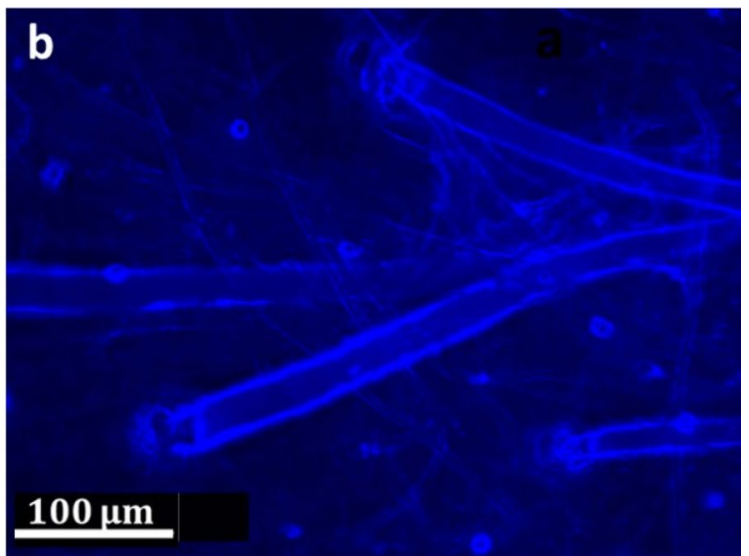

d

$100 \mu \mathrm{m}$

ment of chitinous cuticle with setae was digested for $6 \mathrm{~h}$ in Yatalase solution at $37^{\circ} \mathrm{C}$ and imaged before (c) and after digestion (d). Based on [64] 


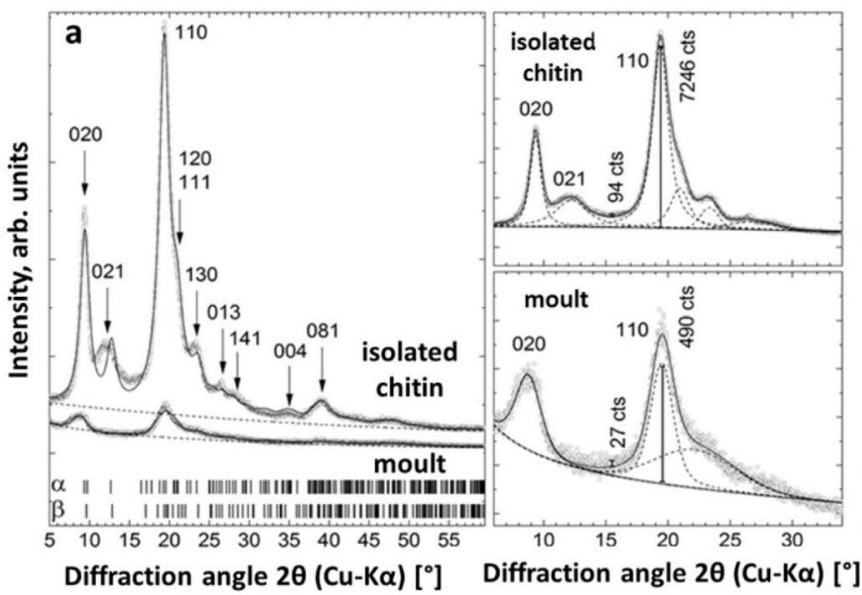

Fig. 6 X-ray diffraction pattern of samples of natural moult cuticle (moult) from $C$. versicolor spider and isolated chitin scaffold (isolated chitin) (a). The good match between experimental (dots) and calculated data (line) provides evidence for the presence of $\alpha$-chitin (left,

sensory detection within the environment, have been evolutionarily conserved in spite of the diverse natural habitats occupied by arthropod species [106, 115-117]. The exoskeletons of spiders are tightly covered by a surprisingly large number of mechanoreceptive hairs [118]. The sensory detection of changes in the environment is facilitated by nerve impulses transmitted by the vibrations of microhairs, a phenomenon described in the middle of the nineteenth century [106, 119]. Changes of the environment may also be detected by proprioception via the touch-sensitive setae [120]. It is known that spider mechanosensors are sensitive to a wide range of stimulus, including substrate vibrations, the gentle whiff of air, micro-strains or deformation in their exoskeleton (for more detail see [120]). Araneae can similarly use wind-sensing setae and vibration-sensitive setae as detectors for sensing prey $[72,121,122]$.

It is also interesting to note that several spider species (mostly theraphosids) use urticating hair-like setae and stridulating setae as a defense strategy [123-127]. Spiders' hairy setae which cover their walking legs (so-called "attachment hairs") also play a crucial role in movement on rough and smooth vertical surfaces [99]. Fibre diffraction patterns showed that crystalline chitin chains were oriented along the long axis of the attachment setae and that intensity of the chitin signal increased dorsally within the seta shaft. The small-angle scattering signals clearly indicated an angular shift of the microtrich structures that branch off the bulk hair shaft and end as the adhesive contact elements in the tip region of the seta. The results reveal the specific structural arrangement and distribution of the chitin fibres within the attachment hair's cuticle, preventing material failure by tensile reinforcement and proper distribution

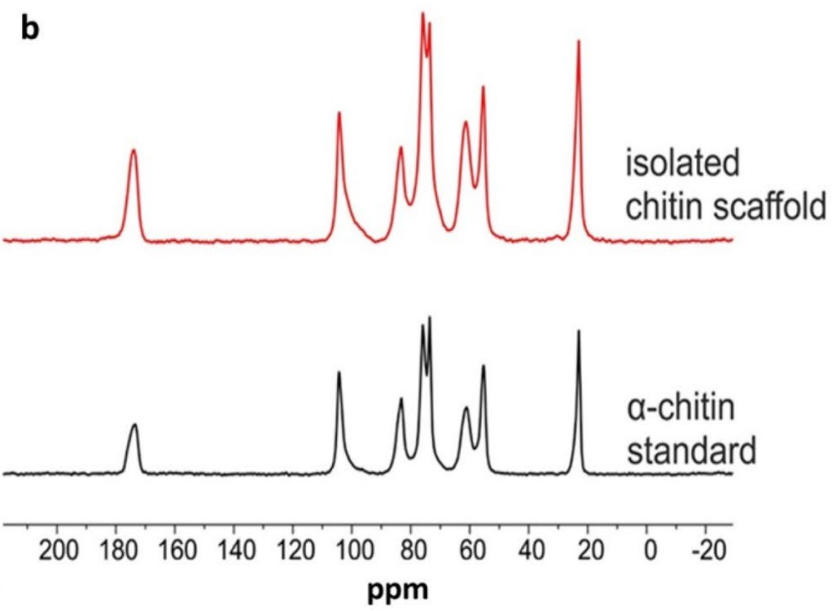

Rietveld refinement, phase identification). For comparison, the theoretical line positions for $\alpha$ - and $\beta$-chitin are also shown. ${ }^{13} \mathrm{C}$ CP/MAS NMR spectra of isolated chitin scaffold (red line) and $\alpha$-chitin (black line) (b). Based on [64]

of stresses that arise upon attachment and detachment. These remarkable biological structures are composed of thousands of specially designed microhairs (see example Fig. 7) and have served as notable inspirations for researchers involved in biomimetic application design [128-131]. Detailed characterization of hydrophobic character of cuticular hair has been described with respect to moults of spiders Avicularia sp. peru purple, please see [66]. Despite many studies to describe and define setae microhairs in arthropods, there remain many mysteries and unsolved biological questions, including the structural and functional role of chitin.

\section{Practical uses of spider chitin}

\subsection{Biomedical application of spider tubular-chitin}

Recently, the global market for regenerative tissue engineering was estimated to reach around 60 billion USD [132]. The modern structure-based tissue engineering requirements necessitate large-scale 3D cell/tissue manufacturing technologies to generate biologically active 3D scaffolds that possess biological, immunological, physicochemical, structural as well as mechanical cues at nano-, micro- and macroscale levels [8]. Generally, artificially fabricated scaffolds must possess biocompatible and ecocompatible character [132] as well as the provision of suitable support for cell growth, migration, differentiation and proliferation [133]. Such 3D constructs serve to mimic the in vivo microenvironment where cells interact and behave according to the mechanical cues obtained from 

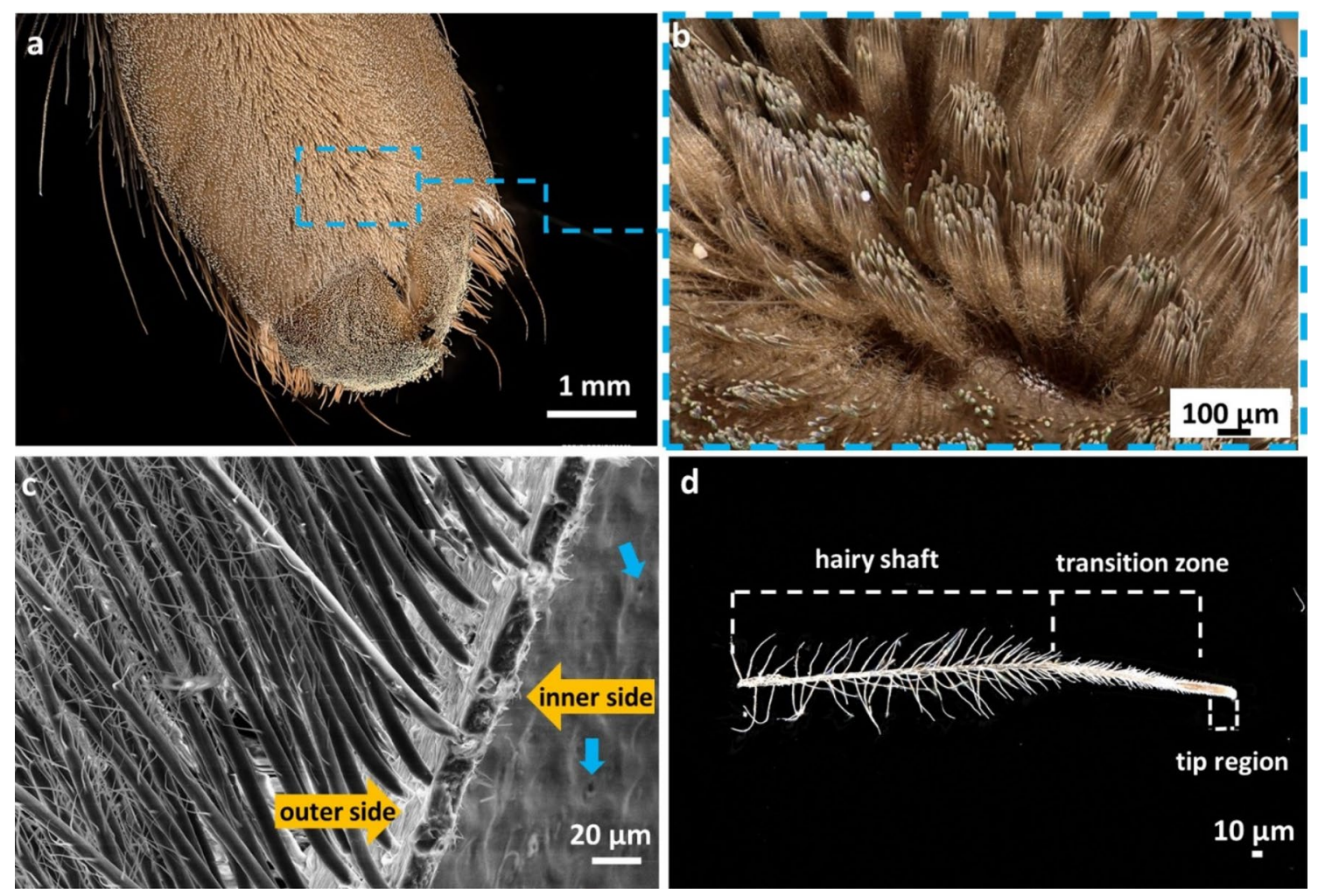

Fig. 7 Digital microscope (a, b, d) and SEM (c) images of Avicularia sp. "Peru purple" moult of a part of the walking leg. The brush-like microstructure and porous cuticle are visible (blue arrows) (c). Inner and outer side of moult are denoted by orange arrows (c). Single

attachment hair isolated from a selected fragment of the walking leg part of moult, digital microscopy image (d) which has been subdivided and denoted for clarity

the surrounding 3D environment [133]. Unfortunately, the production of artificial scaffolds requires special machinery and costly manufacturing technology. Consequently, within the last decade, naturally prefabricated scaffolds have been of high interest for their applications to modern biomedicine. An excellent example of natural 3D matrices for applications in biomedicine are scaffolds isolated from sponges (Porifera) $[134,135]$ and natural films isolated from insect cuticles [136]. The application of 3D naturally pre-structured chitin matrices is an attractive alternative with respect to scaffolding strategies. The dissolving of chitin in LiCl-based solvents may lead to the promotion of undesirable features, such as toxicity and loss of antimicrobial properties. Moreover, important characteristics such as high thermal stability, nano-fibrous structure, hydrophobicity, tensile strength and mechanical properties may also be affected negatively after treatment [136]. Thus, it is very important to generate a facile and robust method for the isolation of naturally $3 \mathrm{D}$ pre-designed matrices.

Recently, the unique and ready-to-use 3D chitinous constructs of poriferan origin that include an interconnected microtubular architecture [137-141] have been applied to various practical applications. These include templates for biomimetical applications such as those obtained under extreme conditions ("extreme biomimetics") [142-145], electrochemistry [146] and environmental science [147, 148]. These investigations follow the trend to seek out new sources of open-pore chitin matrices, foams and scaffolds [149], for express use in biomedical applications.

The use of tarantula moult cuticles as a source of unique tubular centimeter-sized chitin is economically feasible given the relative ease by which it can be prepared and the fact that moults are readily available from spider farming operations worldwide. Along the lines of the experiments described above, scientists recently showed that tubular chitin from Theraphosidae spider Caribena versicolor moulting cuticle, was effective as a scaffold for the tissue engineering of selected mammalian cells [65]. Further, good experimental evidence was provided for the biocompatibility of spider chitin with a human progenitor 

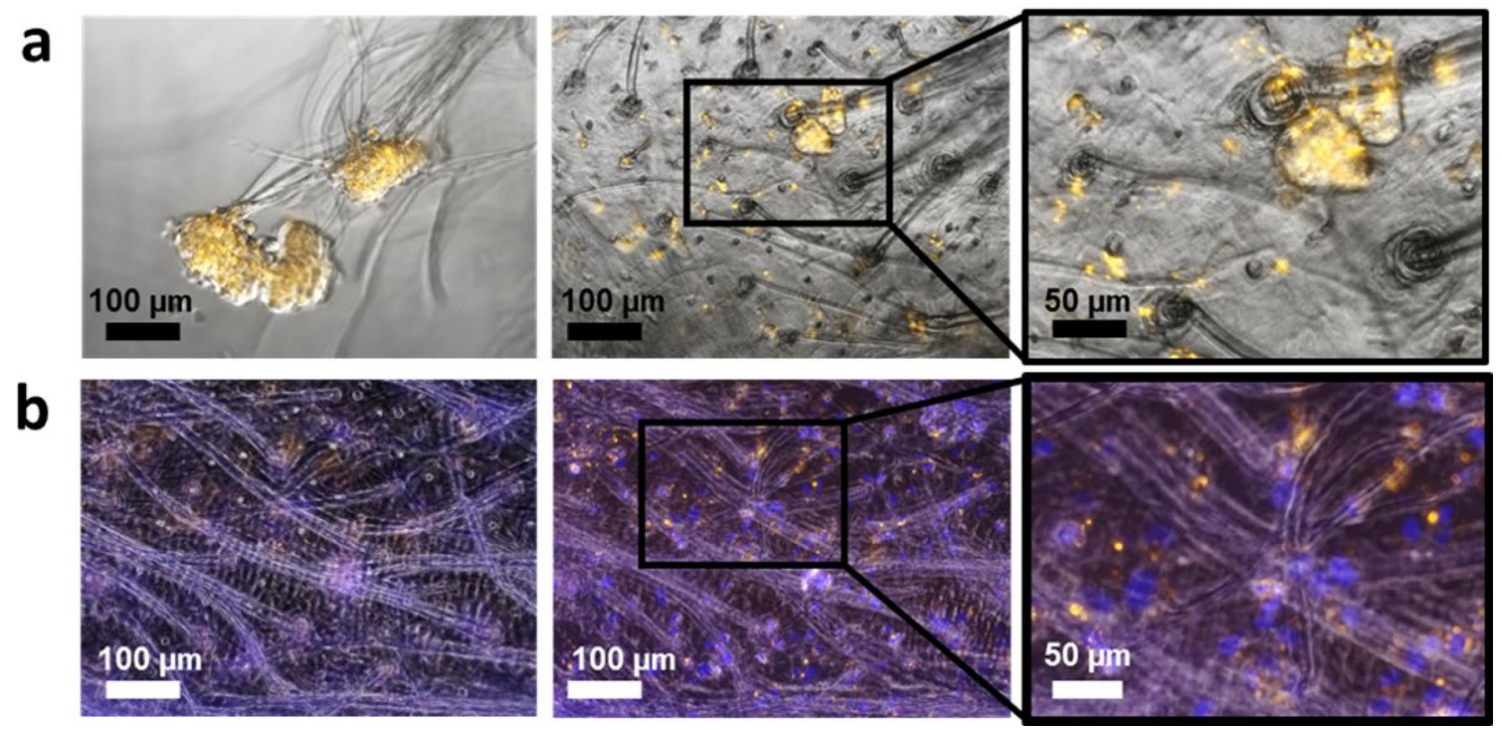

Fig. 8 Cell adhesion on tubular chitin scaffold isolated from C. versicolor. Viable human progenitor cells stained with QTracker (orange) on the chitin setae and the base surface of the scaffold (a). Visualiza- tion of attached cells on the surface of the scaffold by fluorescence microscopy; nuclei are seen in blue (DAPI) (b). Copyright (2020), Elsevier, reproduced with permission [65]
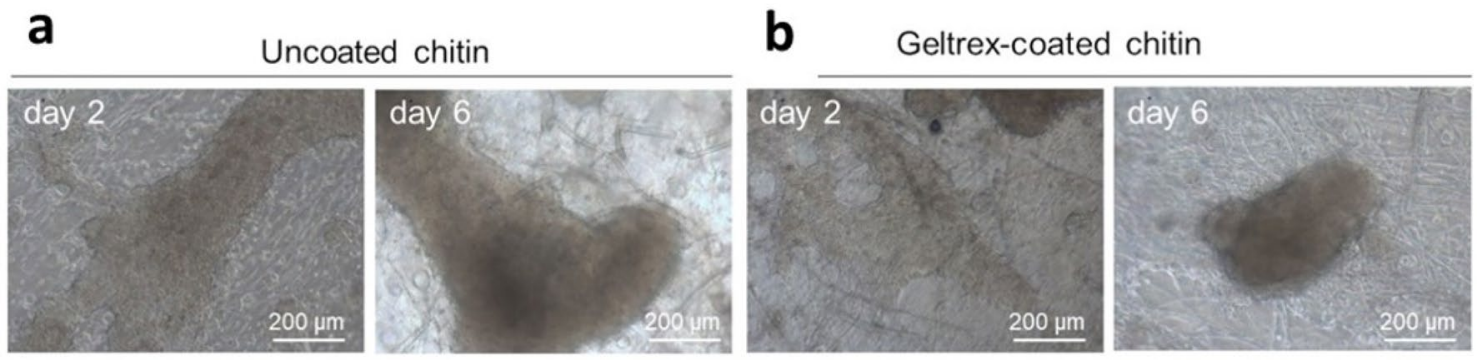

\section{Geltrex-coated chitin (day 30)}
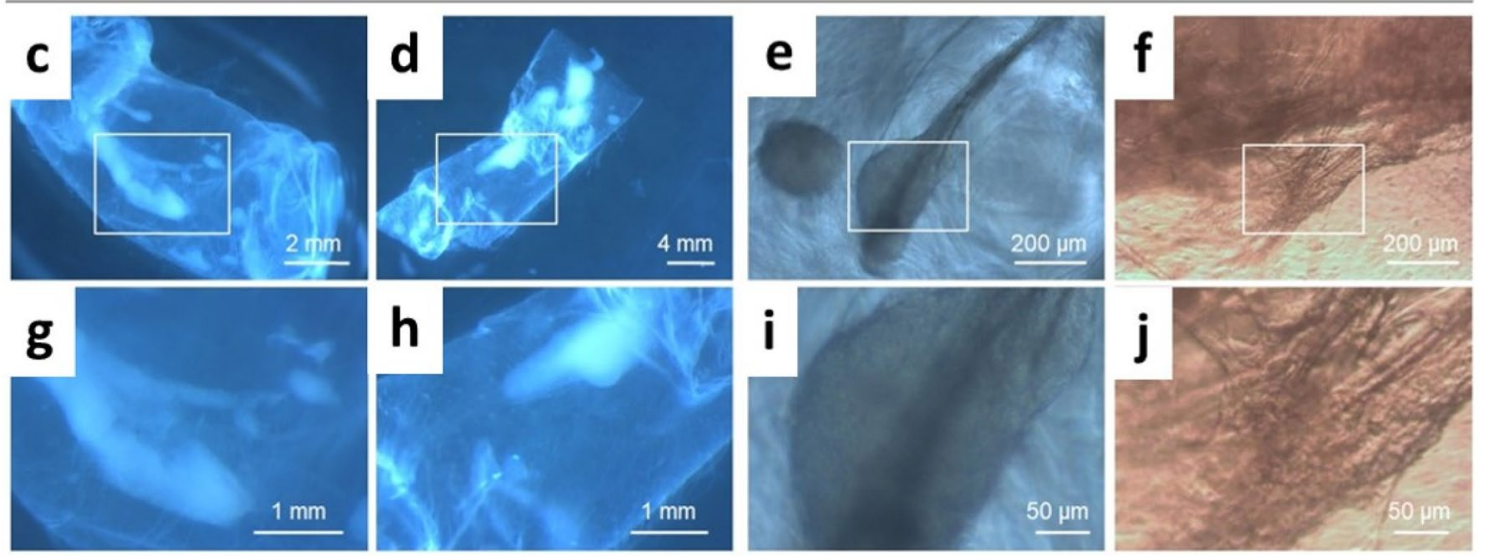

Fig. 9 Attachment and growth of iPSC-CMs on spider chitin scaffolds. Attachment of iPSC-CMs on uncoated (a) and Geltrex-coated chitin scaffolds (b). iPSC-CM muscle fibers formed inside the chitin segments of the tarantula leg after 30 days of cultivation $(\mathbf{c}, \mathbf{d})$.
Attachment of iPSC-CM spheroids on hair-like structures inside (e) and on the edge (f) of the chitin scaffold. Magnified images of the areas indicated in $\mathbf{c}-\mathbf{f}(\mathbf{g}-\mathbf{j})$. Copyright (2020), Elsevier, reproduced with permission [65] 


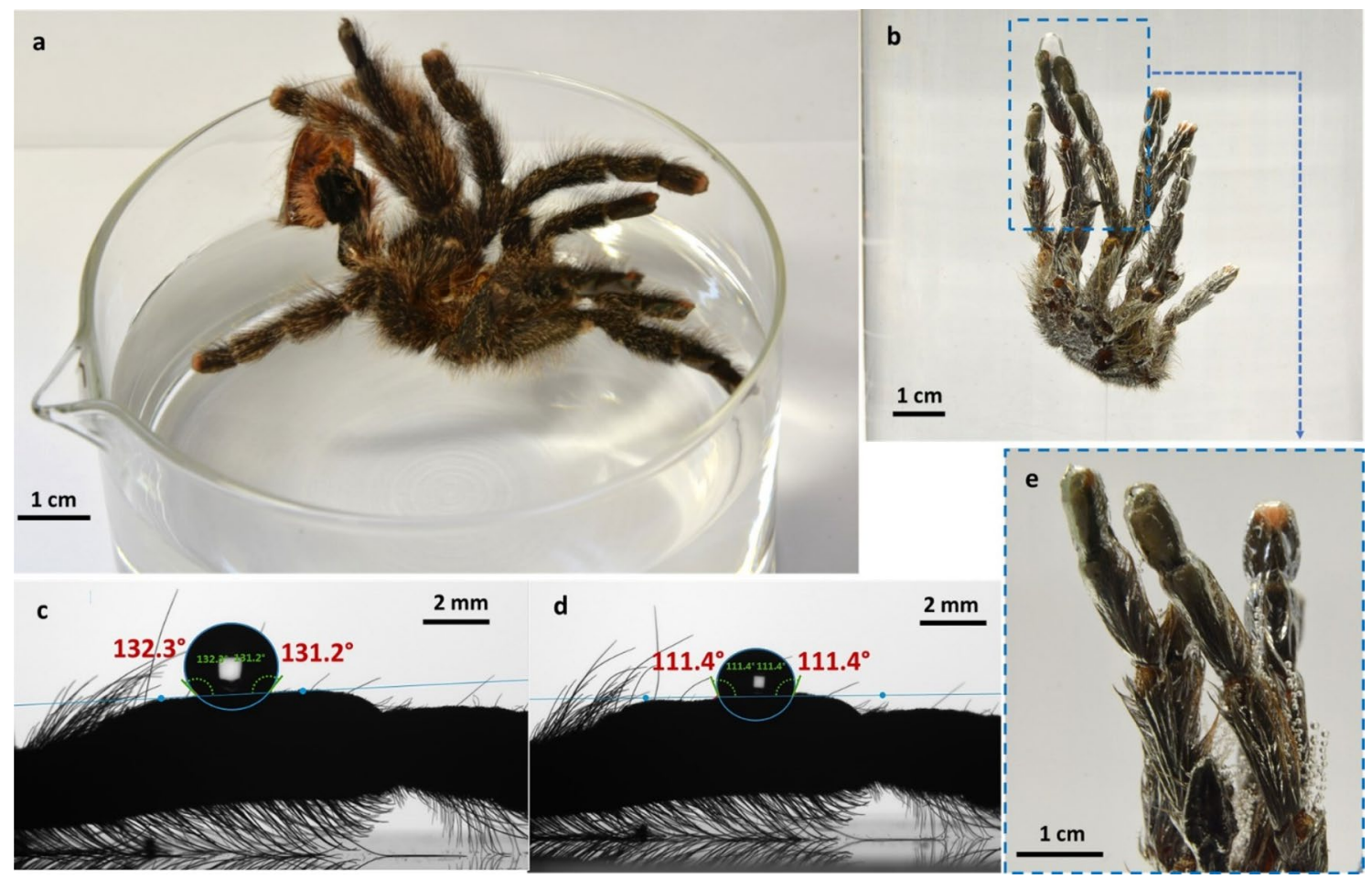

Fig. 10 Optical image of the hydrophobic and light-weight $A$. sp. "Peru purple" moulting cuticle (a). Digital image of hydrophobic moult immersed in water by an external force obtained by load attachment, air bubbles layer is visible on the surface (b, e). Contact angle of water (c) and diiodomethane (d) on moulting cuticle. Copyright (2020), Elsevier, reproduced with permission [66] cell line (hPheo1), as well as for cardiomyocytes differentiated from induced pluripotent stem cells (iPSC-CMs). The 3D tube-like scaffolds isolated from the spider $C$. versicolor differ notably from those of sponge chitin not only in size and porosity but also by the presence of setae (micro-hairs) on the surface of the tubes. This fact makes this naturally prefabricated material very promising from a tissue engineering point of view (determination of behavior of selected human cells in such microenvironment). There was also provided evidence that human progenitor cells (hPheo1) derived from a pheochromocytoma were attached to the chitin surface ( $24 \mathrm{~h}$ after seeding) and seeding large cellular aggregates on the scaffold [65] (see Fig. 8).

Authors have also described the behavior of long-term cultured cardiomyocytes (iPSC-CMs) placed into the culture on spider chitin scaffolds [65]. Beating of cardiomyocytes was observed 1-2 days after reseeding, in keeping with typical iPSC-CM behavior under standard culture conditions. Then, after 1 week, the iPSC-CMs formed spheroids inside the chitin scaffold and attached to the hair-like structures (setae). Interestingly, after prolonged culture period on the C. versicolor scaffold (one month) the iPSC-CMs formed longer, contracting muscle filaments inside the chitin scaffold. Affinity of cardiomyocytes to spider chitin constructs was observed here for the first time (see Fig. 9). The continuous activity of cardiomyocytes (beating) required strong adhesion to a foundation, which, in this case was provided by the chitinous scaffold.

Future research on chitin isolated from the spider's moult will assess how well it can be modified for use as reinforcement for biocomposites. Our rationale is that scaffolds based on chitin powder/nanosilica were found to be efficacious for bone tissue engineering [150] and chitin nanofibers/chitosan films have been found to be effective for wound healing applications [151].

\subsection{Chitin-based spider cuticle for oil-spill remediation}

Nowadays, the global economy in many branches of industry is still based on crude oil [152]. Nevertheless, transport and production of their derivatives are burdened by a high risk of oil spills and resultant pollution. It has been estimated that more than half of the oceanic hydrocarbon pollution originates from human activity [66]. Thus, rapid and effective mitigation using the unique sorption capability of selected biological and artificial materials is critically important. Four main types of oil-spill remediation 

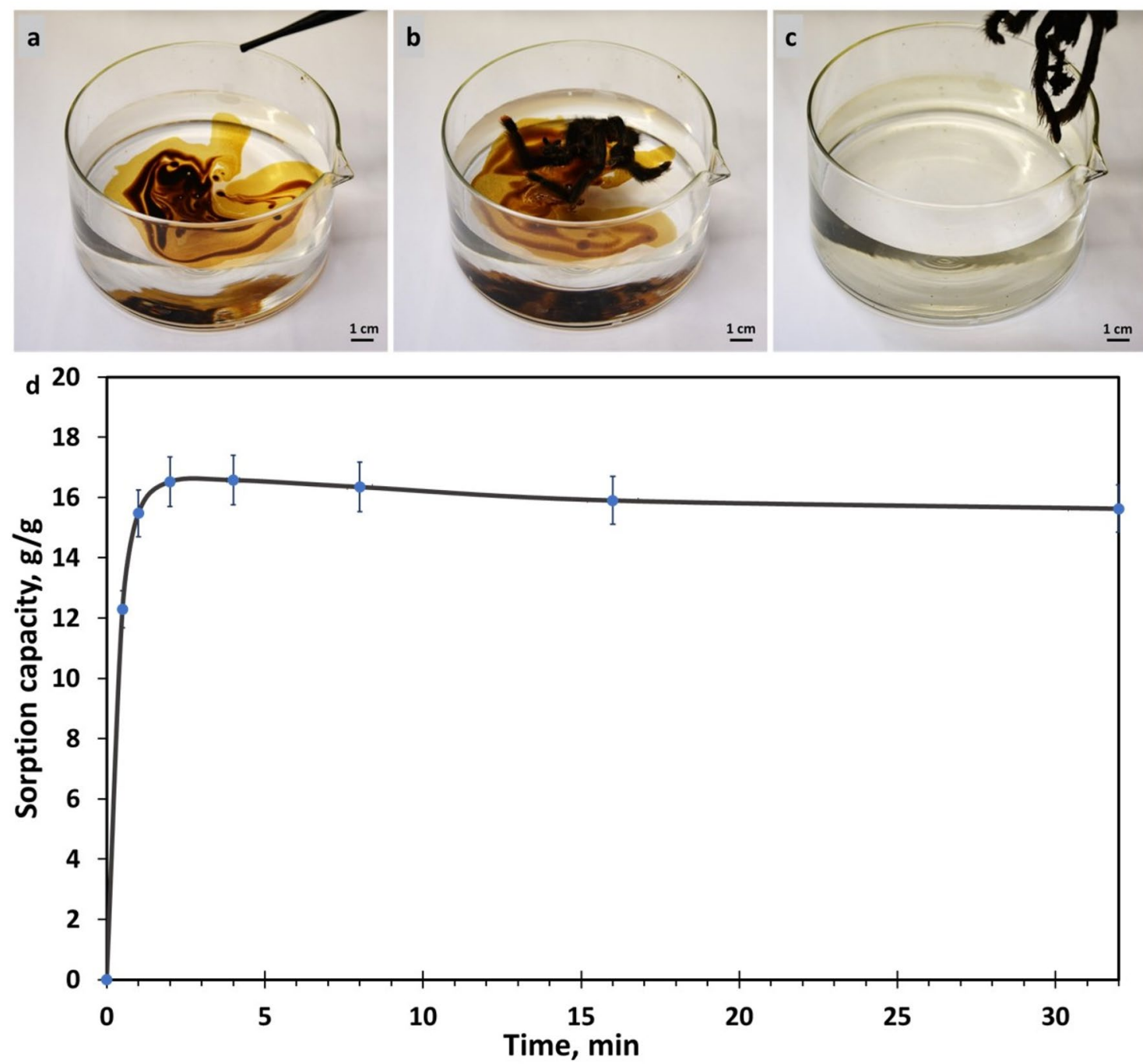

Fig. 11 Crude oil absorption by A. sp. "Peru purple" moulting cuticle at room temperature. Crude oil ( $1 \mathrm{~g}$ ) layer on the water surface $(100 \mathrm{ml})$ in a beaker (a). Moulting cuticle (about $300 \mathrm{mg}$ ) during contact with crude oil (b). Image of oil sorption from the water surface

methods can be distinguished: (I) chemical (e.g., dispersants, solidifiers), (II) in situ burning, (III) bioremediation, and (IV) mechanical recovery (e.g., booms, skimmers, sorbents) [153]. Out of all of these, adsorption controlled by weak intermolecular forces (e.g., van der Waals forces) is the most appropriate and preferred method but is influenced by many factors, including oil viscosity, pore morphology and the hydrophobicity of the sorbents [153-155]. Natural biomaterials are especially attractive as sorbents when considering their biodegradability, renewability, cost-efficiency and easy availability. There are dozens of examples of currently used biosorbents, such as kapok (fibers from the plant Ceiba pentandra) [156, 157], keratins (like human hair) [158] and bird feathers [152], fruit by spider moult after $30 \mathrm{~s}$ of contact (c). Crude oil absorption capacity as a function of time with 5\% error bars (d). Conditions: $60 \mathrm{ml}$ freshwater, $2 \mathrm{~g}$ crude oil, $100 \mathrm{mg}$ sorbent. Based on [66]

peel [159], rice husk ash [160] or barley straw, sawdust or coir fiber [161]. In addition, pure chitin and chitosan from crustaceans were widely described as oil pollutant sorbents [162-166].

Machalowski and co-workers recently proposed the use of moulting cuticles from the spider A. sp. "Peru purple" (Araneae: Theraphosidae: Avicularinae) as a promising crude oil adsorbent [66]. As was mentioned above, spider cuticle represents an excellent example of a biocomposite, which is composed of two main phases-chitin scaffold and bound proteins ( $90 \%$ of total cuticle weight). The unique surface morphology (specific setae arrangement) and a thin layer of waxes also endows this raw material 

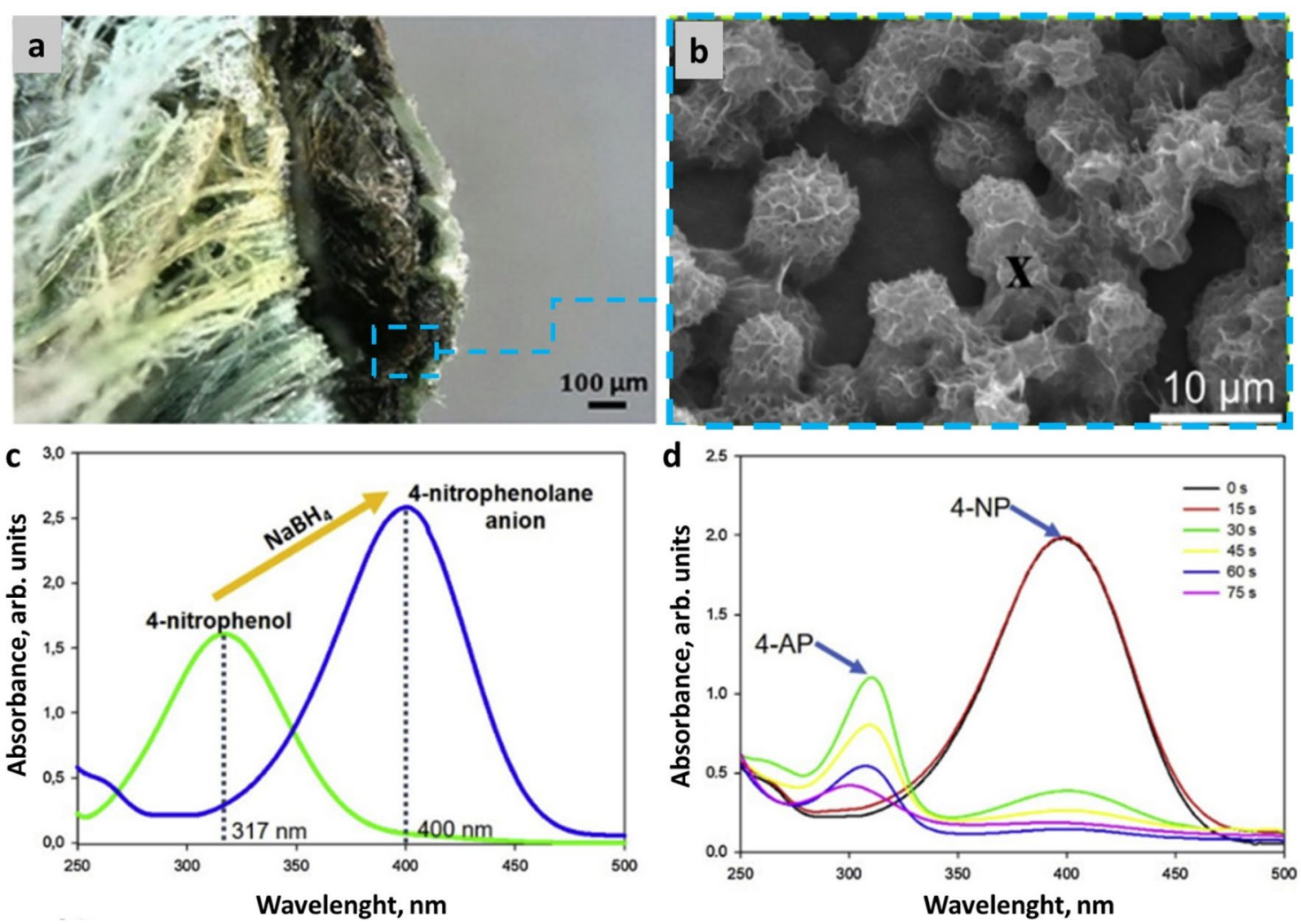

Fig. 12 Stereomicroscopic image of the Chitin- $\mathrm{CuO} / \mathrm{Cu}(\mathrm{OH})_{2}$ catalyst after drying at $80{ }^{\circ} \mathrm{C}$ represent the blue-greenish color typical of copper oxide-containing materials (a). Spherical crystalline structures of $\mathrm{CuO} / \mathrm{Cu}(\mathrm{OH}) 2$ (marked by $\mathrm{X}$ ) of the inner surface of created catalyst (b). UV-Vis spectra of 4-nitrophenol (4-NP) before and after

addition of $\mathrm{NaBH}_{4}$ solution (c). Transformation 4-nitrophenol (4-NP) to 4-aminophenol (4-AM) in the presence of Chitin- $\mathrm{CuO} / \mathrm{Cu}(\mathrm{OH})_{2}$ catalyst (d). Copyright (2020), Elsevier, reproduced with permission [65]

with excellent hydrophobicity and very low surface free energy $(4.47 \pm 0.08 \mathrm{mN} / \mathrm{m}$ ) (see Fig. 10). Under natural conditions, the spiders use this property to avoid getting wet as well as to quickly leave the water surface in the event of a fall. In contrast to other natural biosorbents, this proposed material is capable of remaining on the water surface for a long time with negligible water absorption. The non-homogeneous morphology of the moult makes it suitable for oil spill removal and may be an inspiration for the design of future artificial sorption materials.

Recently, experiments were conducted where crude oil sorption capacities of moult cuticle were determined in different salinities of water [66]. Results suggested that moult cuticle was effective at removing crude oil at $12.6 \mathrm{~g} / \mathrm{g}, 15.8 \mathrm{~g} / \mathrm{g}$ and $16.6 \mathrm{~g} / \mathrm{g}$, respectively, in seawater, distilled water, and freshwater (Fig. 11). These results demonstrate that spider cuticle-based material is more efficient at removing crude oil than such currently used fibrous sorbents as human hairs or cellulosic fibers. Four cycles of sorption-desorption confirmed the reusability of the proposed biosorbent. A possible explanation for the crude oil adsorption mechanism is the brush-like and

microporous structures of the tubular spider moulting cuticles (physical trapping) as well as the interaction between the cuticular wax layers and crude oil.

\subsection{Tubular and porous spider chitin as catalyst component}

In 2019, for the first time porous chitinous tubes isolated from $C$. versicolor spider moult (from walking legs) found application as membranes for catalyst creation [65]. Scientists carried out an experiment whereby a catalyst composed of chitin together with $\mathrm{CuO}$ and $\mathrm{Cu}(\mathrm{OH})_{2}$ phases were used for the reduction of 4-nitrophenol in aqueous solution. These results clearly indicated that the Chitin$\mathrm{CuO} / \mathrm{Cu}(\mathrm{OH})_{2}$ (see Fig. 12) catalyst synthesized in this study possessed good catalytic activity (activity parameter $K-1090.7 \mathrm{~min}^{-1} \mathrm{~g}^{-1}$ ). In comparison with other copperbased catalysts, the Chitin- $\mathrm{CuO} / \mathrm{Cu}(\mathrm{OH})_{2}$ mixture provides a stable composite and rapid conversion and simplifies the removal of catalyst from the reaction mixture. 


\section{Conclusions}

Nature has produced a number of unique materials which can find very specific applications in modern engineering and biotechnology, as well as serve as inspirations for the development of novel materials. The search for biomaterials with novel properties is an ongoing process. It can be concluded here that although overlooked for many years, spiders (especially Theraphosidae) represent a very promising source of $\alpha$-chitin. Spider chitin, especially that from the large-size species being propagated, can be used as a versatile scaffold for many applications. The latest studies have shown that moult cuticles from spiders are a good source of chitin scaffold material that has retained in its natural shape. Use of this material is economically feasible since moults are readily available from spider farms worldwide for large scale and expedient chitin extraction.

We strongly believe that this review will encourage our scientific community to lend their special attention to studying chitin of spider origin. The ease of preparation of chitinous scaffold material from Araneae using our innovative MWI assisted technique should intensify its study and increase the use of spider molt as a viable source for technological and materials science applications in the near future.

Funding Tomasz Machałowski (T.M.) is supported by DAAD (Personal ref. no. 91734605). This research was funded by the Ministry of Science and Higher Education (Poland) (T.M., T.J).

Data availability Not applicable.

Code availability Not applicable.

\section{Compliance with ethical standards}

Conflicts of interest Prof. Werner Müller (Germany). Prof. Giuseppe Falini (Italy). Prof. Rangasami Jayakumar (India). Prof. Talat Baran (Turkey). Dr. Beniamin Kruppke (Germany). Authors declare no conflict of interest.

Ethics approval Not applicable.

Consent to participate All of the coworkers have agreed to participate.

Consent for publication All of the co-workers have agreed to publication.

Open Access This article is licensed under a Creative Commons Attribution 4.0 International License, which permits use, sharing, adaptation, distribution and reproduction in any medium or format, as long as you give appropriate credit to the original author(s) and the source, provide a link to the Creative Commons licence, and indicate if changes were made. The images or other third party material in this article are included in the article's Creative Commons licence, unless indicated otherwise in a credit line to the material. If material is not included in the article's Creative Commons licence and your intended use is not permitted by statutory regulation or exceeds the permitted use, you will need to obtain permission directly from the copyright holder. To view a copy of this licence, visit http://creativecommons.org/licenses/by/4.0/.

\section{References}

1. C. Klinger, S. Żółtowska-Aksamitowska, M. Wysokowski, M.V. Tsurkan, R. Galli, I. Petrenko, T. Machałowski, A. Ereskovsky, R. Martinović, L. Muzychka, O.B. Smolii, N. Bechmann, V. Ivanenko, P.J. Schupp, T. Jesionowski, M. Giovine, Y. Joseph, S.R. Bornstein, A. Voronkina, H. Ehrlich, Mar. Drugs 17, 131 (2019)

2. V. Kovalchuk, A. Voronkina, B. Binnewerg, M. Schubert, L. Muzychka, M. Wysokowski, M.V. Tsurkan, N. Bechmann, I. Petrenko, A. Fursov, R. Martinovic, V.N. Ivanenko, J. Fromont, O.B. Smolii, Y. Joseph, M. Giovine, D. Erpenbeck, M. Gelinsky, A. Springer, K. Guan, S.R. Bornstein, H. Ehrlich, Mar. Drugs 17, 574 (2019)

3. T. Ahamad, M. Naushad, S.M. Alshehri, Int. J. Biol. Macromol 130, 139-147 (2019)

4. M. Schubert, B. Binnewerg, A. Voronkina, L. Muzychka, M. Wysokowski, I. Petrenko, V. Kovalchuk, M. Tsurkan, R. Martinovic, N. Bechmann, V.N. Ivanenko, A. Fursov, O.B. Smolii, J. Fromont, Y. Joseph, S.R. Bornstein, M. Giovine, D. Erpenbeck, K. Guan, H. Ehrlich, Int. J. Mol. Sci. 20, 5105 (2019)

5. B. Binnewerg, M. Schubert, A. Voronkina, L. Muzychka, M. Wysokowski, I. Petrenko, M. Djurović, V. Kovalchuk, M. Tsurkan, R. Martinovic, N. Bechmann, A. Fursov, V.N. Ivanenko, K.R. Tabachnick, O.B. Smolii, Y. Joseph, M. Giovine, S.R. Bornstein, A.L. Stelling, A. Tunger, M. Schmitz, O.S. Taniya, I.S. Kovalev, G.V. Zyryanov, K. Guan, H. Ehrlich, Mater. Sci. Eng. C 109, 110566 (2020)

6. A. Cooper, R. Oldinski, H. Ma, J.D. Bryers, M. Zhang, Carbohydr. Polym. 30, 254-259 (2013)

7. S. Jain, G. Bhanjana, S. Heydarifard, N. Dilbaghi, M.M. Nazhad, V. Kumar, K. Kim, S. Kumar, Carbohydr. Polym. 202, 219-226 (2018)

8. M. Wysokowski, T. Machałowski, I. Petrenko, C. Schimpf, D. Rafaja, R. Galli, J. Zietek, S. Pantovic, A. Voronkina, V.K.V.N. Ivanenko, B.W. Hoeksema, C. Diaz, Y. Khrunyk, A.L. Stelling, M. Giovine, T. Jesionowski, H. Ehrlich, Mar. Drugs 18, 123 (2020)

9. K. Nowacki, I. Stępniak, T. Machalowski, M. Wysokowski, I. Petrenko, C. Schimpf, D. Rafaja, J. Ziętek, S. Pantović, A. Voronkina, V. Kovalchuk, V. Ivanenko, Y. Khrunyk, R. Galli, Y. Joseph, M. Gelinsky, T. Jesionowski, H. Ehrlich, Appl. Phys. A 126, 368 (2020)

10. T.H. Tran, H.-L. Nguyen, D.S. Hwang, J.Y. Lee, H.G. Cha, J.M. Koo, S.Y. Hwang, J. Park, D.X. Oh, Carbohydr. Polym. 205, 392-400 (2019)

11. M. Wysokowski, I. Petrenko, A.L. Stelling, D. Stawski, T. Jesionowski, H. Ehrlich, Polymers 7, 235-265 (2015)

12. H. Merzendorfer, Eur. J. Cell Biol. 90, 759-769 (2011)

13. M. Yadav, P. Goswami, K. Paritosh, M. Kumar, N. Pareek, V. Vivekanand, Bioresour. Bioprocess. 6, 8 (2019)

14. L.Y. Chung, R.J. Schmidt, P.F. Hamlyn, B.F. Sagar, A.M. Andrew, T.D. Turner, J. Biomed. Mater. Res. 28, 463-469 (1994)

15. R.M. Street, T. Huseynova, X. Xu, P. Chandrasekaran, L. Han, W.Y. Shih, W.-H. Shiha, C.L. Schauer, Carbohydr. Polym. 195, 218-224 (2018)

16. J. van Leeuwen, G. A. Norton, S. S. Ndlela, and D. Rudnick, US 9,249,235 B2 (2016). 
17. H. Ehrlich, M. Motylenko, P.V. Sundareshwar, A. Ereskovsky, I. Zgłobicka, T. Noga, T. Płociński, M.V. Tsurkan, E. Wyroba, S. Suski, H. Bilski, M. Wysokowski, H. Stöcker, A. Makarova, D. Vyalikh, J. Walter, S.L. Molodtsov, V.V. Bazhenov, I. Petrenko, E. Langer, A. Richter, E. Niederschlag, M. Pisarek, A. Springer, M. Gelinsky, D. Rafaja, A. Witkowski, D.C. Meyer, T. Jesionowski, K.J. Kurzydłowski, Adv. Funct. Mater. 26, 2503-2510 (2016)

18. M. Wysokowski, T. Jesionowski, H. Ehrlich, Am. Mineral. 103, 665-691 (2018)

19. E. Brunner, P. Richthammer, H. Ehrlich, S. Paasch, P. Simon, S. Ueberlein, K.H. Van Pée, Angew. Chemie-Int. Ed. 48, 97249727 (2009)

20. S. Das, F.D. Gillin, Biochem. J. 280, 641-647 (1991)

21. E. Campos-Góngora, F. Ebert, U. Willhoeft, S. Said-Fernández, E. Tannich, Protist 155, 323-330 (2004)

22. H. Ehrlich, M. Krautter, T. Hanke, P. Simon, C. Knieb, S. Heinemann, H. Worch, J. Exp. Zool. 308B, 473-483 (2007)

23. H. Ehrlich, E. Steck, M. Ilan, M. Maldonado, G. Muricy, G. Bavestrello, Z. Kljajic, J.L. Carballo, S. Schiaparelli, A. Ereskovsky, P. Schupp, R. Born, H. Worch, V.V. Bazhenov, D. Kurek, V. Varlamov, D. Vyalikh, K. Kummer, V.V. Sivkov, S.L. Molodtsov, H. Meissner, G. Richter, S. Hunoldt, M. Kammer, S. Paasch, V. Krasokhin, G. Patzke, E. Brunner, W. Richter, Int. J. Biol. Macromol. 47, 141-145 (2010)

24. M. Wysokowski, V.V. Bazhenov, M.V. Tsurkan, R. Galli, A.L. Stelling, H. Stöcker, S. Kaiser, E. Niederschlag, G. Gärtner, T. Behm, M. Ilan, A.Y. Petrenko, T. Jesionowski, H. Ehrlich, Int. J. Biol. Macromol. 62, 94-100 (2013)

25. E. Brunner, H. Ehrlich, P. Schupp, R. Hedrich, S. Hunoldt, M. Kammer, S. Machill, S. Paasch, V.V. Bazhenov, D.V. Kurek, T. Arnold, S. Brockmann, M. Ruhnow, R. Born, J. Struct. Biol. 168, 539-547 (2009)

26. G. Falini, S. Albeck, S. Weiner, L. Addadi, Science 271, 67-69 (1996)

27. X. Du, G. Fan, Y. Jiao, H. Zhang, X. Guo, R. Huang, Z. Zheng, C. Bian, Y. Deng, Q. Wang, Z. Wang, X. Liang, H. Liang, C. Shi, X. Zhao, F. Sun, R. Hao, J. Bai, J. Liu, W. Chen, J. Liang, W. Liu, Z. Xu, Q. Shi, X. Xu, G. Zhang, X. Liu, Gigascience 6, 1-12 (2017)

28. A. Miglioli, R. Dumollard, T. Balbi, L. Besnardeau, L. Canesi, U. Genova, C. Europa, Proc. R. Soc. B 286, 20192043 (2019)

29. M.S. Fernández, F. Valenzuela, J.I. Arias, J.L. Arias, J. Struct. Biol. J. 196, 187-196 (2016)

30. R. Chandran, L. Williams, A. Hung, K. Nowlin, D. Lajeunesse, Micron 82, 74-85 (2016)

31. H. Merzendorfer, L. Zimoch, J. Exp. Biol. 206, 4393-4412 (2003)

32. J.F.V. Vincent, U.G.K. Wegst, Arthropod Struct. Dev. 33, 187199 (2004)

33. K.M. Rudall, Adv. In Insect Phys. 1, 257-313 (1963)

34. S. Liu, J. Sun, L. Yu, C. Zhang, J. Bi, F. Zhu, M. Qu, C. Jiang, Q. Yang, Molecules 17, 4604-4611 (2012)

35. G.J.G. Davies, D.P. Knight, F. Vollrath, PLoS ONE 8, e73225 (2013)

36. M. Kaya, O. Seyyar, T. Baran, S. Erdogan, M. Kar, Int. J. Biol. Macromol. 65, 553-558 (2014)

37. J. Zhang, M. Feng, X. Lu, C. Shi, X. Li, J. Xin, G. Yue, S. Zhang, Carbohydr. Polym. 190, 148-155 (2018)

38. I. Hamed, F. Özogul, J.M. Regenstein, Trends Food Sci. Technol. 48, 40-50 (2016)

39. P.J. Seear, G.A. Tarling, G. Burns, W.P. Goodall-Copestake, E. Gaten, Ö. Özkaya, E. Rosato, BMC Genomics 11, 582 (2010)

40. H.M. Harðardóttir, R. Male, F. Nilsen, C. Eichner, M. Dondrup, S. Dalvin, Comp. Biochem. Physiol. -Part A 227, 123-133 (2019)
41. J.B. Zeng, Y.S. He, S.L. Li, Y.Z. Wang, Biomacromol 13, 1-11 (2012)

42. G. Wagner, J. Lo, R. Laine, M. Almeder, Experientia 49, $317-$ 319 (1993)

43. W.J. Tang, J.G. Fernandez, J.J. Sohn, C.T. Amemiya, W.J. Tang, J.G. Fernandez, J.J. Sohn, C.T. Amemiya, Curr. Biol. 25, 897900 (2015)

44. K. Nakashima, S. Kimura, Y. Ogawa, S. Watanabe, S. Soma, T. Kaneko, L. Yamada, H. Sawada, C.H. Tung, T.M. Lu, J.K. Yu, A. Villar-Briones, S. Kikuchi, N. Satoh, Nat. Commun. 9, 3402 (2018)

45. H. Merzendorfer, in Sugar Code Fundam. Glycosci., edited by H.-J. Gabius (Wiley-VCH, Weinheim, 2009), pp. 217-229.

46. M. Wysokowski, M. Zatoń, V.V. Bazhenov, T. Behm, A. Ehrlich, A.L. Stelling, M. Hog, H. Ehrlich, Paleobiology 40, 529-540 (2014)

47. B. Duan, Y. Huang, A. Lu, L. Zhang, Prog. Polym. Sci. 82, 1-33 (2018)

48. M. Florek, E. Fornal, P. Gómez-romero, E. Zieba, W. Paszkowicz, J. Lekki, J. Nowak, A. Kuczumow, Mater. Sci. Eng. C 29, 1220-1226 (2009)

49. M. Kaya, M. Mujtaba, H. Ehrlich, A.M. Salaberria, T. Baran, C.T. Amemiya, R. Galli, L. Akyuz, I. Sargin, J. Labidi, Carbohydr. Polym. 176, 177-186 (2017)

50. B. Duan, K. Shou, X. Su, Y. Niu, G. Zheng, Y. Huang, A. Yu, Y. Zhang, H. Xia, L. Zhang, Biomacromol 18, 2080-2089 (2017)

51. K.M. Rudall, W. Kenchington, Biol. Rev. 48, 597-636 (1973)

52. M. Li, C. Jiang, Q. Wang, Z. Zhao, Q. Jin, J. Xu, Front. Plant Sci. 7, 37 (2016)

53. K.Y. Zhu, H. Merzendorfer, W. Zhang, J. Zhang, S. Muthukrishnan, Annu. Rev. Entomol. 61, 177-196 (2016)

54. R. Jayakumar, K.P. Chennazhi, S. Srinivasan, Int. J. Mol. Sci. 12, 1876-1887 (2011)

55. I. Younes, M. Rinaudo, Mar. Drugs 13, 1133 (2015)

56. X. Zhang, M. Rolandi, J. Mater. Chem. B 5, 2547-2559 (2017)

57. P. Rameshthangam, D. Solairaj, G. Arunachalam, P. Ramasamy, J. Enzym. 1, 20-43 (2018)

58. A. Anitha, S. Sowmya, P.T.S. Kumar, S. Deepthi, K.P. Chennazhi, H. Ehrlich, M. Tsurkan, R. Jayakumar, Prog. Polym. Sci. 39, 1644-1667 (2014)

59. J. Zdarta, Ł. Klapiszewski, M. Wysokowski, M. Norman, A. Kołodziejczak-Radzimska, D. Moszyński, H. Ehrlich, H. Maciejewski, A.L. Stelling, T. Jesionowski, Mar. Drugs 13, 2424 (2015)

60. K.G. Collatz, T. Mommsen, Comp. Biochem. Physiol. 52A, 465-476 (1975)

61. D.M. Stewart, A.W. Martin, J. Comp. Physiol. B 149, 121-136 (1982)

62. M. Nyffeler, K. Birkhofer, Sci. Nat. 104, 30 (2017)

63. M.F. Bagaturov, A. Jammu, J. Br. Tarantula Soc. 20, 78-88 (2005)

64. T. Machałowski, M. Wysokowski, M.V. Tsurkan, R. Galli, S. Żółtowska-Aksamitowska, I. Petrenko, K. Czaczyk, M. Kraft, M. Bertau, N. Bechmann, K. Guan, S.R. Bornstein, A. Voronkina, A. Fursov, M. Bejger, K. Biniek-Antosiak, W. Rypniewski, M. Figlerowicz, O. Pokrovsky, T. Jesionowski, H. Ehrlich, Molecules 24, 3736 (2019)

65. T. Machałowski, M. Wysokowski, S. Żółtowska-Aksamitowska, N. Bechmann, B. Binnewerg, M. Schubert, K. Guan, S.R. Bornstein, K. Czaczyk, O. Pokrovsky, M. Kraft, M. Bertau, C. Schimpf, D. Rafaja, M. Tsurkan, R. Galli, H. Meissner, I. Petrenko, A. Fursov, A. Voronkina, M. Figlerowicz, Y. Joseph, T. Jesionowski, H. Ehrlich, Carbohydr. Polym. 226, 115301 (2019)

66. T. Machałowski, M. Wysokowski, I. Petrenko, A. Fursov, B. Fazilov, M. Rahimi-Nasrabadi, M.M. Amro, H. Meissner, Y. 
Joseph, H. Ehrlich, T. Jesionowski, J. Environ. Manage. 261, 110218 (2020)

67. G. R. Mullen and R. S. Vetter, in Med. Vet. Entomol., edited by G. R. Mullen and L. A. Durden, 3rd ed. (Academic Press, 2019), pp. 507-531.

68. R.S. Vette, M.K. Rust, J. Kansas Entomol. Soc. 83, 306-312 (2010)

69. L.R. Benavides, G. Hormiga, Invertebr. Syst. 34, 144-191 (2020)

70. F. Álvarez-Padilla, R.J. Kallal, G. Hormiga, Bull. Am. Museum Nat. Hist. 2020, 1-108 (2020)

71. N. I. Platnick, Nat. Hist. Museum Bern Online Http//Wsc.Nmbe. Ch (2019).

72. F.G. Barth, Scholarpedia 10, 7267 (2015)

73. W. Fabiano-Da-Silva, J. Paulo, L. Guadanucci, M. Bernardino, Syst. Biodivers. 17, 650-668 (2019)

74. R.J. Raven, Bull. Am. Museum Nat. Hist. 182, 1-180 (1985)

75. M.A. Aguilera, Ecol. Evol. 9, 5802-5809 (2019)

76. M. Arent, Https://Arent.P1/Budowa-Aparatu-Jadowego-uPtasznikow/19.04.2020 (2020).

77. Y. Politi, E. Pippel, A.C.J. Licuco-Massouh, L. Bertinetti, H. Blumtritt, F.G. Barth, P. Fratzl, Arthropod Struct. Dev. 46, 30-38 (2017)

78. B. Bar-On, F.G. Barth, P. Fratzl, Y. Politi, Nat. Commun. 5, 3894 (2014)

79. Y. Politi, M. Priewasser, E. Pippel, P. Zaslansky, J. Hartmann, S. Siegel, C. Li, F.G. Barth, P. Fratzl, Adv. Funct. Mater. 22, 2519-2528 (2012)

80. T. Guggolz, S. Henne, Y. Politi, R. Sch, J. Morphol. 276, 14331447 (2015)

81. H.C. Browning, Proc. R. Soc. B 131, 65-86 (1942)

82. H. Nemenz, Osterr Akad Wiss Math-Nat KI Abt I(164), 65-76 (1955)

83. F.G. Barth, Cell Tissue Res. 144, 409-433 (1973)

84. F.G. Barth, Zeitschrift Für Zellforsch. Und Mikroskopische Anat. 97, 137-159 (1969)

85. F.G. Barth, Zeitschrift Für Zellforsch. Und Mikroskopische Anat. 104, 87-107 (1970)

86. J. E. Dalingwater, in Ecophysiol. Spiders, edited by W. Nentwig (Springer Berlin Heidelberg, Berlin, 1987), pp. 3-15.

87. A. Krishnakumaran, Q. J. Microsc. Sci. 101, 433-438 (1960)

88. A. Krishnakumaran, Zeitschrift Fur Vergleiehende Physiol. 44, 478-486 (1961)

89. J. Clarke, Bull. Br. Arachnol. Soc. 7, 37-47 (1986)

90. H.M. Lease, B.O. Wolf, J. Morphol. 271, 759-768 (2010)

91. M.T. Sewell, Ann. Entomol. Soc. Am. 48, 107-117 (1955)

92. A. Krishnakumaran, H.A. Schneiderman, Biol. Bull. 139, 520538 (1970)

93. M. Erko, M.A. Hartmann, I. Zlotnikov, C. Valverde Serrano, P. Fratzl, Y. Politi, J. Struct. Biol. 183, 172-179 (2013)

94. B.K. Hsiung, D.D. Deheyn, M.D. Shawkey, T.A. Blackledge, Sci. Adv. 1, e1500709 (2015)

95. W. Nentwig, Ecophysiology of spiders (Springer-Verlag, Berlin, 1987), pp. 1-131

96. B.-K. Hsiung, T.A. Blackledge, M.D. Shawkey, J. Exp. Biol. 218, 3632-3635 (2015)

97. M.T. Sewell, Nature 167, 857-858 (1951)

98. M.E. McConney, C.F. Schaber, M.D. Julian, F.G. Barth, V.V. Tsukruk, J.R. Soc, Interface 4, 1135-1143 (2007)

99. C.F. Schaber, S. Flenner, A. Glisovic, I. Krasnov, M. Rosenthal, H. Stieglitz, C. Krywka, M. Burghammer, M. Muller, S.N. Gorb, Interface 16, 20180692 (2019)

100. C.L. Alsberg, C.A. Hedblom, J. Biol. Chem. 6, 483-497 (1909)

101. J.L. Cloudsley-Thompson, Nature 165, 692-693 (1950)

102. G. Krishnan, N.N. Ramachandran, M.S. Santanam, Nature 176, 557-558 (1955)

103. G. Krishnan, Nature 175, 904 (1955)
104. C. Valverde, H. Leemreize, B. Bar-On, F.G. Barth, P. Fratzl, E. Zolotoyabko, Y. Politi, J. Struct. Biol. J. 193, 124-131 (2016)

105. A.V. Ivanina, H.I. Falfushynska, E. Beniash, H. Piontkivska, I.M. Sokolova, J. Exp. Biol. 220, 3209-3221 (2017)

106. H. Ehrlich, Marine Biological Materials of Invertebrate Origin (Springer International Publishing, Cham, Switzerland, 2019, pp. $1-329$ ).

107. H. Ehrlich, in Biomim. Biomater. Struct. Appl., edited by A. J. Ruys (Woodhead Publishing Limited, Cambridge, UK, 2013), pp. 46-66.

108. M. Kaya, T. Baran, Int. J. Biol. Macromol. 75, 7-12 (2015)

109. M. Kaya, I. Sargin, I. Sabeckis, D. Noreikaite, D. Erdonmez, A.M. Salaberria, J. Labidi, V. Baublys, T. Vaida, Carbohydr. Polym. 163, 162-169 (2017)

110. M. Kaya, M. Mujtaba, E. Bulut, B. Akyuz, L. Zelencova, Carbohydr. Polym. 132, 9-16 (2015)

111. H. Greven, M. Kaya, I. Sargin, T. Baran, R. Møbjerg Kristensen, M. Vinther Sørensen, Turkish J. Zool. 43, 416-424 (2019)

112. A. Mol, M. Kaya, M. Mujtaba, B. Akyuz, Entomol. Res. 48, 480-489 (2018)

113. M. Kaya, B. Bitim, M. Mujtaba, T. Koyuncu, Int. J. Biol. Macromol. 81, 443-449 (2015)

114. S. Shang, L. Zhu, J. Fan, Carbohydr. Polym. 93, 561-573 (2013)

115. P.E. Howse, Syrup Zoolological Soc. London 23, 167-198 (1968)

116. T. Sminia, L. Barendsen, J. Morphol. 165, 31-39 (1980)

117. N. Kouyama, T. Shimozawa, M. Hisada, Experientia 37, 379-380 (1981)

118. F.G. Barth, A spider's world: senses and behavior (SpringerVerlag, Heidelberg, 2002), pp. 5-357

119. F. Leydig, Z Wiss Zoo 3, 280-307 (1851)

120. F. G. Barth, in Ecol. Anim. Senses, edited by G. von der Emde and E. Warrant (Cham, Switzerland, 2016), pp. 27-58.

121. J. Speck-Hergenroder, F.G. Barth, Experientia 44, 13-14 (1988)

122. C.F. Schaber, S.N. Gorb, F.G. Barth, J.R. Soc, Interface 9, 1254 $1264(2012)$

123. E.W. Minch, J. Arachnol. 5, 133-137 (1977)

124. R. Bertani, J.P.L. Guadanucci, Zool. 30, 403-418 (2013)

125. R. Bertani, T. Boston, Y. Evenou, J.P.L. Huadanucci, Br. Arachnol. Soc. 12, 395-398 (2003)

126. C.S. Fukushima, R. Bertani, Zookeys 659, 1-185 (2017)

127. A. Galleti-Lima, P.L. Guadanucci, Zool. Anz. 283, 58-68 (2019)

128. S. Flenner, I. Greving, M. E. Larsson, C. Schaber, C. Krywka, S. Gorb, M. Rosenthal, M. Burghammer, and M. Mueller, in Verhandlungen Der Dtsch. Phys. Gesellschaft e.V. (2018).

129. C. Schaber, in 3rd Sino-German Symp. Biomimetics Learn. from Anim. Intell. Robot. (Nanjing, 2017).

130. C. Schaber, S. Flenner, I. Krasnov, C. Krywka, E. Di Cola, M. Rosenthal, M. Burghammer, M. Mueller, and S. Gorb, in 109th Annu. Meet. Ger. Zool. Soc. (Kiel, 2016).

131. S. Flenner, C. Schaber, I. Greving, M. E. Larsson, D. Laipple, I. Krasnov, H. Stieglitz, S. Gorb, M. Rosenthal, and M. Burghammer, M. ; Mueller, in 28th ESRF User Meet. (Grenoble, 2018).

132. M. Pierfrancesco, C.M. Beatrice, D. Serena, Glob. J. Nanomedicine 3, 107-112 (2018)

133. Q.L. Loh, C. Choong, Tissue Eng. B 19, 485-502 (2013)

134. V.V. Mutsenko, V.V. Bazhenov, O. Rogulska, D.N. Tarusin, K. Schütz, S. Brüggemeier, E. Gossla, A.R. Akkineni, H. Meißner, A. Lode, S. Meschke, A. Ehrlich, S. Petović, R. Martinović, M. Djurović, A.L. Stelling, S. Nikulin, S. Rodin, A. Tonevitsky, M. Gelinsky, A.Y. Petrenko, B. Glasmacher, H. Ehrlich, Int. J. Biol. Macromol. 104, 1966-1974 (2017)

135. V. Mutsenko, O. Gryshkov, O. Rogulska, A. Lode, M. Petrenko, Alexander Yu. Gelinsky, B. Glasmache, and H. Ehrlich, in Mar. Biomater. Tissue Eng. Appl. Chitinous (Springer Nature, Singapore, 2019), pp. 285-307. 
136. M. Kaya, A.M. Salaberria, M. Mujtaba, J. Labidi, T. Baran, P. Mulercikas, F. Duman, Int. J. Biol. Macromol. 106, 1062-1070 (2018)

137. J.A. Cruz-Barraza, J.L. Carballo, A. Rocha-Olivares, H. Ehrlich, M. Hog, PLoS ONE 7, e42049 (2012)

138. K. Kunze, H. Niemann, S. Ueberlein, R. Schulze, H. Ehrlich, E. Brunner, P. Proksch, K.H. Van Pée, Mar. Drugs 11, 1271 (2013)

139. L. A. Shaala, H. Z. Asfour, D. T. A. Youssef, S. ZółtowskaAksamitowska, M. Wysokowski, M. Tsurkan, R. Galli, H. Meissner, I. Petrenko, K. Tabachnick, V. N. Ivanenko, N. Bechmann, L. V. Muzychka, O. B. Smolii, R. Martinovi'c, Y. Joseph, T. Jesionowski, and H. Ehrlich, Mar. Drugs 17, 92 (2019).

140. J. Fromont, S. Żółtowska-Aksamitowska, R. Galli, H. Meissner, D. Erpenbeck, J. Vacelet, C. Diaz, M.V. Tsurkan, I. Petrenko, D.T.A. Youssef, H. Ehrlich, Zool. Anz. 280, 21-29 (2019)

141. J. Vacelet, D. Erpenbeck, C. Diaz, H. Ehrlich, J. Fromont, Zool. Anz. 280, 14-20 (2019)

142. M. Wysokowski, M. Motylenko, J. Walter, G. Lota, J. Wojciechowski, H. Stöcker, R. Galli, A.L. Stelling, C. Himcinschi, E. Niederschlag, E. Langer, V.V. Bazhenov, T. Szatkowski, J. Zdarta, I. Pertenko, Z. Kljajić, T. Leisegang, S.L. Molodtsov, D.C. Meyer, T. Jesionowski, H. Ehrlich, RSC Adv. 4, $61743-$ $61752(2014)$

143. M. Wysokowski, K. Materna, J. Walter, I. Petrenko, A.L. Stelling, V.V. Bazhenov, Ł. Klapiszewski, T. Szatkowski, O. Lewandowska, D. Stawski, S.L. Molodtsov, H. Maciejewski, H. Ehrlich, T. Jesionowski, Int. J. Biol. Macromol. 78, 224-229 (2015)

144. M. Wysokowski, T.J. Szalaty, T. Jesionowski, M. Motylenko, D. Rafaja, I. Koltsov, H. Stöcker, V.V. Bazhenov, H. Ehrlich, A.L. Stelling, J. Beyer, J. Heitmann, S. Petovic, M. Đurović, Mater. Chem. Phys. 188, 115-124 (2017)

145. I. Petrenko, V.V. Bazhenov, R. Galli, M. Wysokowski, J. Fromont, P.J. Schupp, A.L. Stelling, E. Niederschlag, H. Stöker, V.Z. Kutsova, T. Jesionowski, H. Ehrlich, Int. J. Biol. Macromol. 104, 1626-1632 (2017)

146. I. Stepniak, M. Galinski, K. Nowacki, M. Wysokowski, P. Jakubowska, V.V. Bazhenov, T. Leisegang, H. Ehrlich, T. Jesionowski, RSC Adv. 6, 4007-4013 (2016)

147. D. Schleuter, A. Günther, S. Paasch, H. Ehrlich, Z. Kljajić, T. Hanke, G. Bernhard, E. Brunner, Carbohydr. Polym. 92, 712-718 (2013)

148. H. Ehrlich, in Blue Biotechnol. Prod. Use Mar. Mol., edited by S. La Barre and S. S. Bates (Wiley-VCH, Weinheim, 2018), pp. 821-854.
149. K.S. Chow, E. Khor, Biomacromol 1, 61-67 (2000)

150. K. Madhumathi, P.T.S. Kumar, K.C. Kavya, T. Furuike, H. Tamura, S.V. Nair, R. Jayakumar, Int. J. Biol. Macromol. 45, 289-292 (2009)

151. R. Shelma, W. Paul, C.P. Sharma, Trends Biomater. Artif. Organs 22, 111-115 (2008)

152. A.O. Ifelebuegu, A. Johnson, Crit. Rev. Environ. Sci. Technol. 47, 964-1001 (2017)

153. J. Ge, H. Zhao, H. Zhu, J. Huang, L. Shi, S. Yu, Adv. Mater. 21, 10459-10490 (2016)

154. A. Bayat, S.F. Aghamiri, A. Moheb, G.R. Vakili-Nezhaad, Chem. Eng. Technol. 28, 1525-1528 (2005)

155. R. Hesas Hoseinzadeh, M. Sharifzadeh Baeia, H. Rostami, J. Gardy, J. Environ. Manage. 241, 525-534 (2018)

156. T.T. Lim, X. Huang, Ind. Crops Prod. 26, 125-134 (2007)

157. J. Wang, Y. Zheng, A. Wang, J. Environ. Sci. (China) 25, 246$253(2013)$

158. A. O. Ifelebuegu, T. V. Anh Nguyen, P. Ukotije-Ikwut, and Z. Momoh, J. Environ. Chem. Eng. 3, 938-943 (2015)

159. M. Abdullah, S.H.A. Muhamad, S.N. Sanusi, S.I.S. Jamaludin, A.H.R. Mohamad, Nor Fadilah Mohammad. J. Appl. Environ. Biol. Sci. 6, 59-63 (2016)

160. L. Vlaev, P. Petkov, A. Dimitrov, S. Genieva, J. Taiwan Inst. Chem. Eng. 42, 957-964 (2011)

161. S. Sabir, Crit. Rev. Environ. Sci. Technol. 45, 1916-1945 (2015)

162. A.L. Ahmad, S. Sumathi, B.H. Hameed, Adsorpt. Sci. Technol. 22, 75-88 (2004)

163. A.L. Ahmad, S. Sumathi, B.H. Hameed, Chem. Eng. J. 108, 179-185 (2005)

164. F. C. de F. Barros, L. C. G. Vasconcellos, T. V. Carvalho, and R. F. do Nescimento, Electron. J. Chem. 6, 2-6 (2014).

165. C. I. da Silva Grem, B. N. Barreto Lima, W. Ferreira Carneiro, Y. Gomes de Carvalho Queirós, and C. R. Elias Mansur, Polímeros 23, 705-711 (2012).

166. A.R. Gentili, M.A. Cubitto, M. Ferrero, M.S. Rodriguéz, Int. Biodeterior. Biodegrad. 57, 222-228 (2006)

Publisher's Note Springer Nature remains neutral with regard to jurisdictional claims in published maps and institutional affiliations. 